\title{
Sting Operations, Undercover Agents, and Entrapment
}

\section{Citation}

Bruce L. Hay, Sting Operations, Undercover Agents, and Entrapment, 70 Mo. L. Rev. (2005).

\section{Published Version}

http://scholarship.law.missouri.edu/mlr/vol70/iss2/2/

\section{Permanent link}

http://nrs.harvard.edu/urn-3:HUL.InstRepos:12991689

\section{Terms of Use}

This article was downloaded from Harvard University's DASH repository, and is made available under the terms and conditions applicable to Other Posted Material, as set forth at http:// nrs.harvard.edu/urn-3:HUL.InstRepos:dash.current.terms-of-use\#LAA

\section{Share Your Story}

The Harvard community has made this article openly available.

Please share how this access benefits you. Submit a story.

\section{Accessibility}




\section{Missouri Law Review}

Volume 70

Issue 2 Spring 2005

Article 2

Spring 2005

\section{Sting Operations, Undercover Agents, and Entrapment}

Bruce Hay

Follow this and additional works at: http://scholarship.law.missouri.edu/mlr

Part of the Law Commons

\section{Recommended Citation}

Bruce Hay, Sting Operations, Undercover Agents, and Entrapment, 70 Mo. L. Rev. (2005)

Available at: http://scholarship.law.missouri.edu $/ \mathrm{mlr} / \mathrm{vol} 70 /$ iss $2 / 2$

This Article is brought to you for free and open access by the Law Journals at University of Missouri School of Law Scholarship Repository. It has been accepted for inclusion in Missouri Law Review by an authorized administrator of University of Missouri School of Law Scholarship Repository. 


\title{
Sting Operations, Undercover Agents, and Entrapment
}

\author{
Bruce Hay*
}

\section{INTRODUCTION}

Charles Nunez reputedly financed his drug habit by making explosives and selling them to gang members in western Massachusetts. 'In August 1995 he was approached by Jose Colon, one of his drug suppliers. Colon said he wanted some pipe bombs "to blow up the Solids," a rival gang. Nunez readily agreed to make the bombs. Together they went shopping for ingredients, accompanied by Colon's friend Frank Montanez. They bought gunpowder and fuse material at a Connecticut gun store, and picked up hardware at the local Home Depot. ${ }^{2}$ En route, Nunez boasted of his previous deals and showed off his technical knowledge of explosives. Once back home, Nunez made nine short-fused pipe bombs filled with gunpowder, nails, and screws. "[W]hen you light this," Nunez warned, "you better run. It has nails and metal balls. If you throw it [it] will kill everybody." Colon left with the bombs stuffed in a duffel bag, paying Nunez $\$ 75$.

It was all a setup. Nunez was the victim of a "sting operation" conducted by undercover police agents. Colon, the drug dealer, was a police informant. Montanez, the passenger, was an undercover state trooper. The police had orchestrated the entire transaction. Colon had worn a wire when visiting $\mathrm{Nu}$ nez; the car had contained a hidden video camera; the police were listening and lying in wait as the deal closed. Nunez was arrested and charged with unlawfully possessing and selling the nine pipe bombs. He was sent to prison for ten years-for a crime staged by the police.

This Article is the first systematic economic analysis of undercover police sting operations, their role in the legal system, and the courts' use of the "entrapment" defense to regulate their use. ${ }^{3}$ Sting operations, of which the

* Professor of Law, Harvard University. Thanks to John Hay, Phil Heymann, Louis Kaplow, Steve Shavell, Andrew Song, Jennifer Zacks, and workshop participants at Harvard for helpful comments. The research was supported by the Olin Center for Law, Economics and Business at Harvard.

1. This account is drawn from the United States v. Nunez, 146 F.3d 36, 37 (1st Cir. 1998), along with the appellate briefs in the case (No. 97-1411).

2. The conviction was sustained on appeal

3. There is an extensive literature on the entrapment defense, but it focuses on the doctrinal foundations and formulations of the defense, frequently attempting to sort out the ambiguities in the courts' definition of the defense. For a recent sample of this literature, which contains citations to work in the area, see Ronald J. Allen et al., Clarifying Entrapment, 89 J. CRIM. L. \& CRIMINOLOGY, 407 (1999). There is also extensive literature on the ethical problems raised by sting operations. Probably the 
Nunez case is a fairly typical example, are a common but controversial law enforcement technique-controversial because the police participate in, or even orchestrate, the very crime for which the defendant is convicted. The principal purpose of this Article is to examine how sting operations lower the crime rate by identifying offenders and deterring crime.

The defining feature of a sting operation is that through covert means, the authorities create or facilitate the very offense of which the defendant is convicted. Normally this is done by having an undercover agent hold out some sort of bait, or opportunity, to commit a crime, and then punishing the person who takes the bait. The obvious advantage of this technique is that the crime can be caught on tape, thus eliminating many of the evidentiary difficulties of ordinary law enforcement. ${ }^{4}$ But it is this "manufactured" quality of the offense that makes sting operations so troubling. (For example, Charles Nunez was convicted of the "staged" sale of pipe bombs to the undercover agent. He was not convicted of the "real" pipe bomb sales to gangs he was suspected of.) What business do law enforcement officials have encouraging, or aiding, the commission of crimes?

The economic inquiry is partly motivated by questions of law enforcement policy: what purposes do sting operations serve? what are their advantages and drawbacks relative to other enforcement methods? when is a given type of sting operation desirable? The inquiry is also motivated by corresponding questions faced by courts: should the target of a successful sting operation be punished for his offense? under what circumstances? What, in other words, is the proper structure of the "entrapment defense" and related judicial doctrines?

In some respects, the problem is similar to the difficulties posed by penalizing criminal attempts. A sting victim who (as in the Nunez case) is arrested before he does any harm is in much the same situation as an individual who is arrested for unsuccessfully attempting to commit a crime. As the arrestee has, by assumption, caused no harm in either case, the question naturally arises: why should he be punished? This problem has prompted a lively

most extensive ethical examination is contained in GARY T. MARX, UNDERCOVER: Police SurveILlanCE IN AMERICA (1988). See also Gerald Dworkin, The Serpent Beguiled Me and I Did Eat: Entrapment and the Creation of Crime, 4 J. LAW \& PHIL. 17 (1985). One student note proposes an economic analysis of entrapment, but confines its focus to the tradeoff between deterring and encouraging crime as a result of police creation of criminal opportunities. See David J. Elbaz, Note, The Troubling Entrapment Defense: How About an Economic Approach?, 36 AM. CRIM. L. REV. 117 (1999). Unlike the present article, the Note does not explicitly distinguish between the informational and deterrent functions of sting operations, and does not attempt a model of the optimal conditions for conviction.

4. Nunez might well have been guilty of other bomb sales in Massachusetts, but that was never charged or proven. The pipe bomb sale of which he was convicted occurred only because a police agent solicited it. 
debate in the context of criminal attempts. ${ }^{5}$ Sting operations differ, however, in that it is the government that prompts the criminal attempt for which the sting victim is arrested and punished. Our focus will be on the rationales for permitting, and limiting, this type of government activity.

This Article focuses on two distinct functions of sting operations. One is the informational, or investigatory, function of identifying individuals who are engaged in (or likely to engage in) criminal activity. The second is the behavioral function of deterring individuals from engaging in (independent) criminal activity: the threat of being caught in a sting may scare individuals away from genuine criminal opportunities that would otherwise seem appealing. Though complementary in some respects, these functions are also in some tension with each other. A sting operation that does not serve informational purposes may be good for deterrent purposes, and vice versa. Their problematic relation is a main theme of the Article.

The Article is organized as follows. Part I is a general overview of the nature of sting operations, their purposes, their potential advantages over other enforcement methods, and the dangers they pose. Parts II and III analyze, respectively, the informational and deterrent effects of sting operations. Part IV considers the relation between the informational and deterrent effects, emphasizing the tensions between them.

Part V attempts a model of a socially desirable sting operation, balancing its informational and/or deterrent value against the danger of entrapping otherwise-innocent individuals. ${ }^{6}$ The model creates a framework for identifying desirable sting operations, a framework that is necessarily very general in character. To apply it to particular cases would require knowledge of parameters whose value is an empirical question the Article does not attempt to quantify. Part VI briefly discusses some general applications to entrapment doctrine. Part VII concludes.

\section{RATIONALES AND HAZARDS OF STING OPERATIONS}

\section{A. Nature and Range of Sting Operations}

For our purposes, a sting operation is defined as any effort by the authorities to encourage wrongdoing, with the intention of punishing the offenses that result. Normally a sting operation is carried out by agents acting undercover, that is, concealing the fact that they work for the authorities. An agent might be a full-time police officer disguised as a private citizen. Or an agent might be a private citizen, often a crook hoping for leniency in sentenc-

5. See, e.g., Steven Shavell, Foundations of Economic Analysis of LAW pt. 5 (2004); David D. Friedman, Impossibility, Subjective Probability, and Punishment for Attempts, 20 J. LEGAL STUD. 179 (1991).

6. The model draws on the well-developed economic analysis of law enforcement. See SHAVELL, supra note 5, at ch. 22-24, and the references cited therein. 
ing, covertly working as a government informant. The critical feature is that the agent is authorized to somehow promote or facilitate (using those terms broadly) the unlawful activity of others, who are then penalized for that crime (including the attempted crime). We will use the terms "target" or "sting victim" to refer to the individuals who are thus caught and charged.

Sting operations come in two basic types. The first type has the agent pose as a participant in unlawful activity, such as a buyer or seller of illegal goods or services. ${ }^{8}$ In a familiar example, an agent might seek to purchase or sell narcotics from a suspected drug dealer; if the target makes the sale, he is prosecuted. Or an agent might pose as a peddler of child pornography; whoever buys his wares is arrested. In another familiar example, an agent seeks to bribe a public official, who is then arrested if he accepts the bribe. Likewise, an agent might pose as a buyer of trade secrets, as an illegal gun merchant, as a broker of pirated software, as a foreign agent interested in buying national security secrets, as a dealer in eagles and other protected species, or even (in a recent example) as a trafficker in human body organs. There are also cases in which agents pose as suppliers of stinger missiles designed to blow commercial aircraft out of the sky. ${ }^{9}$

In other cases of this first type, the agent poses not as a buyer or seller, but as a confederate or coconspirator of the target. For example, an undercover agent helps a gang plan a bank robbery, and the gang members are arrested when they arrive at the bank. An agent infiltrates a terrorist cell and helps plot an assassination, for which the cell members are arrested shortly before carrying out the plan. An agent agrees to help fabricate counterfeit money or other valuable items, and then his fellow counterfeiters are arrested. An agent helps drug traffickers import cocaine or some other illegal substance, and the traffickers are arrested when the contraband arrives. An agent helps run a health care fraud operation, in which insurers are billed for bogus claims, and then nabs the organizers.

The second basic type of sting operation sets up a decoy by having an agent pose as a prospective victim of unlawful activity. For example, a plainclothes cop walks alone late at night in a secluded area, inviting attack by, and then arresting, would-be muggers or rapists. ${ }^{10}$ Or a cop poses as a vagrant

7. Most of the examples to follow are drawn from newspaper articles and judicial case reports.

8. Among the best known recent cases are Abscam, in which members of Congress took bribes in exchange for influencing immigration authorities, and Operation Greylord, in which Chicago judges took bribes in exchange for fixing cases.

9. Other examples include sting operations in which agents buy counterfeit money or luxury goods such as Rolex watches; stolen credit cards; stolen identities obtained from social security cards; worthless securities marketed by fly-by-night brokers; stolen or forged art. Or they offer their services as professional hit men, arsonists, burglars, and so forth.

10. For a police manual on this technique, see Charles BeEne, DeCoy Ops: FightiNG STREET CRIME UNDERCOVER (1992). 
sleeping on the street, with a wad of $\$ 20$ bills protruding from his pockets; whoever tries to grab the money is arrested. Or a fancy car is left apparently unattended on the street, with the doors unlocked and the keys in the ignition; the police pounce if someone tries to drive off with the car. Or an agent poses as a naïve investor, "easy prey" for a scam artist who goes to jail after trying to bilk the agent. Or to take a common recent example involving the internet: pretending to be an adolescent, a cop strikes up an on-line friendship with a pedophile and agrees to meet him somewhere for sex; the police arrest the target when he shows up. Another tactic is to convince the target to deal in a larger quantity of narcotics than originally contemplated by the target, triggering a sentencing enhancement.

The examples I have given all involve enforcement of the criminal laws. It is worth emphasizing, however, that the legal system makes use of stings in many civil cases as well, to enforce administrative licensing and regulatory requirements. For example, an underage agent is filmed buying alcohol or cigarettes at a store whose license to sell such goods is then suspended. Or a black undercover agent applies for an apartment (or job, or bank loan) and is told nothing is available; minutes later a less qualified white agent applies and is told the opposite; the target is then charged with violating antidiscrimination laws. An industrial concern is fined after arranging to have its wastes illegally dumped by trash haulers who turn out to be undercover environmental police. A mail-order business is ordered shut down after bilking consumer protection investigators posing as customers. ${ }^{1}$

Law enforcement aside, stings are also used by private or public organizations and associations to protect themselves from corruption or theft. ${ }^{12}$ For example, a firm creates some enticement for employees to violate a company policy - such as the use of drugs, alcohol, or company computers to view pormography-and fires those who fall into the trap. A company leaves money or valuable items apparently unattended and discharges employees who take the bait. Creators of copyrighted business guides deliberately put false information in their material, and then take legal action against those who take the bait by copying the false information. An employee is suspected of theft, and the firm has another employee go along with the scheme in order to catch the suspect red-handed. Companies create opportunities for disgruntled employees to sell their secrets to rival firms. A jealous husband deliberately gives his wife an opportunity to commit adultery and files for divorce if she succumbs. A mob boss or military dictator, concerned about disloyalty in

11. Other examples: agents place a stuffed deer in the woods during the offseason, and hunters who shoot at it lose their hunting licenses; black agents take a job in order to determine whether black employees are being harassed on the job; agents pretend to be purchasers of a business to determine whether taxes have been properly paid; or agents use stings to enforce civil forfeiture laws against laundered money, drug proceeds, illegal aliens, and so on.

12. See generally Arthur S. Hulnick, Dirty Tricks for Profit: Covert Action in Private Industry, 14 INT'L J. INTELLIGENCE \& COUNTERINTELLIGENCE 529 (2001). 
the ranks, covertly incites and then ruthlessly suppresses plots to overthrow him. ${ }^{13}$ Interestingly, even police departments use sting operations against their own undercover agents to catch rogue agents. ${ }^{14}$ History is also full of examples of sting operations. ${ }^{15}$

What unites all of these examples, and defines them as sting operations, is that the authorities somehow encourage the infraction then penalized. We will use "encourage" very broadly to encompass any action designed to create apparent opportunities for crime, or to make its commission easier or more attractive. We also use the term "authorities" very broadly to mean whoever has the power to impose the penalty in question. In the case of criminal penalties, the authorities are the legal system; in the case of nonlegal sanctions (e.g., terminating a relationship), the authorities may be a private individual or organization. For clarity of exposition, most of our attention will be on the use of stings by the police to enforce the criminal laws, but it will be evident that the analysis carries over to their use in civil law enforcement and in organizational management.

\section{B. Law Enforcement Rationales}

\section{Informational and Behavioral Functions}

Why would the government want to encourage infractions that it is responsible for preventing? ${ }^{16}$ Our analysis will emphasize two law enforcement

13. A chilling recent example is reported about the Saddam Hussein regime in Iraq. Officers from unit A would awaken the officers of unit B in the middle of the night, point guns at their heads, and say, "It's a coup, brother. Are you with us?" Anyone who said "yes" immediately got a bullet in the brain. See Bill Keller, Springtime for Saddam, N.Y. TIMES, Apr. 6, 2002, at A15.

14. Other examples: private sting operations to enforce trademarks; to catch participants in "gray markets" for electronic goods and the like; to exclude unsavory characters from private clubs; to sell illegal cellular phone services or long-distance phone cards; or stings by animal protection societies to catch the illegal treatment of animals.

15. A random sample: The first modern police forces employed professional criminals as double agents to provoke crimes that would then be punished. Church inquisitors covertly urged parishioners to commit heresy, and excommunicated (or worse) those who fell for the ruse. Tsars and other autocrats routinely tested the loyalty of their underlings by employing agents provocateurs. (Z.B. Zubatov, a Tsarist police chief, told dissidents: "We shall provoke you to acts of terror and then crush you," quoted in MARX, supra note 3, at 60.) Even the gods have used sting operations; the biblical lord's purpose in ordering Abraham to slay his beloved Isaac was apparently to tempt him to commit the crime of disobedience. The suffering of Job was also a sting of sorts, testing his loyalty.

16. European observers are often surprised at the powers given police in this country to involve themselves in crime in order to enforce the law. See Gary T. Marx, 
functions of sting operations-two avenues by which encouraging infractions may serve preventive purposes. ${ }^{17}$

\section{a. Informational Functions}

One purpose of sting operations is investigatory-to identify those who are engaged in, or likely to engage in, criminal activity. A target's response to the temptations held out by the government may signal his propensity to commit the offense in question; punishing him is then justified, presumably, on incapacitation grounds. If an undercover agent seeks to buy narcotics from the target, and the target quickly produces a large quantity packaged for sale, this may be taken as an indication that he is in the business of dealing drugs and (perhaps) should be incarcerated. If an agent posing as a job applicant is turned down because she is a woman, this may indicate that the employer is also discriminating against "real" applicants on the basis of sex.

Testing of this sort is often the explicit purpose of sting operations. In some cases, the police suspect a given individual of unlawful activity but lack sufficient evidence to prove it. A sting is then set up so that the target can commit the offense in conditions where evidence is easy to get. In the case of D.C. mayor Marion Barry, for example, the police had heard rumors that Barry was using crack cocaine. So Barry's girlfriend, now working as an FBI informer, lured him into smoking crack in a hotel room, where a hidden camera recorded everything. Similarly, in the Nunez pipe-bomb case mentioned earlier, the word on the street was that Nunez was selling pipe bombs, and the purpose of the sting was to catch him in the act.

In other cases, the sting's objective is to identify unknown offenders or would-be offenders. An unidentified male attacks a series of female joggers in a park. To catch him, an undercover female cop jogs through the park with a stakeout team watching. A man tries to grab her and is charged with the assault. A rash of thefts occurs in an office building; a cash box is then deliberately left in an unlocked office in order to catch the thief red-handed. Unidentified judges on a court are rumored to be fixing cases in exchange for bribes; agents pretending to be lawyers offer bribes to randomly chosen judges, who are then nabbed if they accept. A military agency is concerned that some of its employees may be security risks; it creates some temptation for them to leak information and takes legal action against the ones who succumb.

Who Really Gets Stung? Some Issues Raised by the New Police Undercover Work, 28 CRIME \& DELINQUENCY 165, 169 (1982).

17. This distinction is not novel. See, e.g., People v. Holloway, 55 Cal. Rptr. 2d 547, 559 (Cal. Ct. App. 1996), averruled by People v. Fuhrman, 67 Cal. Rptr. 2d 1 (Cal. 1997); Louis Michael Seidman, The Supreme Court, Entrapment, and Our Criminal Justice Dilemma, 1981 SUP. CT. REV. 111, 140-42. But their economic structure, and the tension between them, have not to my knowledge been examined. 
In each of these examples, the aim of the sting is to get the target to reveal information about himself. Notice that the sting may or may not yield enough information to convict the target of offenses other than the one manufactured by the police. In the jogger example, the arrest may turn up enough evidence, a confession or eyewitness testimony, to convict the defendant of other attacks; or perhaps there is insufficient evidence to convict him of anything except the assault on the agent. In either event, the legal system treats the sting as having identified someone who should be taken off the streets. ${ }^{18}$

\section{b. Deterrent Functions}

The second function of stings is the behavioral one of deterring unlawful activity. Would-be culprits are less likely to break the law when they know that an apparently genuine criminal opportunity may be a police trap. Potential confederates become less trustworthy. If a dealer of illegal weapons knows that a certain number of buyers are really plainclothes cops (or real buyers who have been "flipped" by the police), he will cut back on his sales and perhaps leave the business altogether. Potential victims also become less inviting. If a would-be mugger or rapist fears that a prospective victim is in fact a police decoy, he may think twice before acting on his violent urges.

Achieving these deterrent effects is the obvious goal of many sting operations. This is especially clear in cases where the government announces in advance that it will be using sting operations to catch offenders. For example, employees in sensitive positions are often told that their integrity will be periodically tested by undercover agents. Government licensing boards warn liquor merchants that teenage agents will be attempting to buy alcohol from them, and that any seller caught in the sting will lose his license. Police issue press releases announcing that agents are being sent into the streets to pose as drug dealers.

\section{c. The Difference Between Informational and Deterrent Functions}

The difference between informational or investigatory functions on one hand and deterrent functions on the other requires a good deal of emphasis. Sometimes it is quite clear that the government is trying to catch and punish wrongdoers. This is most evident in cases where the government keeps the existence of the sting operation a well-guarded secret. The idea is to get the wrongdoer to trust the undercover agent so that he will commit his crime in "plain view" (that is, in front of surveillance cameras). If catching such

18. Notice also that in using stings to gather incriminating information, the police may not necessarily be interested in prosecuting the target. Their objective, rather, may be to pressure the target into providing information about his confederatesespecially higher-ups in a criminal organization-by threatening him with jail time if he does not cooperate. 
criminals is the objective, the more the target believes his apparent confederates or victims are genuine, the better.

In deterrent stings, the opposite holds. The government wants to sow distrust among crooks so that (ideally) every crook is afraid that his confederates or victims are agents. This is why the government sometimes widely publicizes the existence of sting operations. Such announcements would be inexplicable if the government's objective were solely to identify wrongdoers. If the police simply wanted to catch actual or potential drug purchasers, it would hardly do to say publicly that it was sending out agents to transact with them, for this would scare many purchasers away. But scaring them away may be precisely the point. If so, advertising the existence of undercover operations makes eminent sense. ${ }^{19}$ Hence one urban mayor's warning that some drug dealers on the street were actually police officers standing ready to arrest their customers: "“We want everybody to know that the next drug buy may be from a police officer." 20

This is not to suggest that informational and behavioral functions of stings are always mutually exclusive. A sting may perform both at once. A heavily publicized buy-and-bust program, for example, may both scare some dealers off the street and also enable the police to identify and convict the ones who remain. But analytically the two functions are separate. Indeed, as our discussion of warnings suggests, there is some tension between the two. Advancing one may mean compromising the other-a problem we will return to.

\section{Potential Advantages over Other Enforcement Methods}

Stings are not the only way of pursuing the informational and behavioral objectives. There are also other methods which do not involve the potentially troubling deceptions associated with sting operations. Why resort to stings? What advantages might they have over alternative methods which would not require the government to encourage or participate in crime? Let us briefly compare the alternatives.

\section{a. Ex Post Enforcement}

One general alternative is to rely purely on ex post enforcement - that is, waiting for a crime to happen and then arresting and punishing the perpetrators. A well-known difficulty with this option is that for many offenses, the only witnesses are willing participants. Obvious examples include the trade in

19. Of course, such announcements may serve other purposes as well, such as persuading the public that the police are doing their job.

20. Gary T. Marx, Under-the-Covers Undercover Investigations: Some Reflections on the State's Use of Sex and Deception in Law Enforcement, CRIM. JuST. ETHICS (Winter/Spring 1992), at 13, 13 (quoting Washington Mayor Marion Barry, News Conference, 1988). The mayor quoted is none other than Marion Barry, who made the remark a few years before his own arrest for smoking crack cocaine. 
drugs and other illegal items, organized crime, corruption, espionage. With the witnesses remaining silent (even if they are found, they can take the Fifth), the police often have insufficient evidence to convict. What convictions they do get may be based on very imperfect evidence, with a corresponding risk of error.

A separate difficulty with ex post enforcement is that it may simply come too late. Terrorists, for example, may be undeterred by the threat of criminal penalties, even if there are no evidentiary obstacles to conviction. They may be suicide bombers; even if they are not, they may welcome punishment as a form of martyrdom. The only way to prevent them from inflicting catastrophic losses is to catch them before they strike. So too with other undeterrables, such as predatory sex offenders. Compulsive child molesters often continue for years or even decades before their victims finally come forward. By the time they are caught through ex post methods, they have already done unacceptable harm.

\section{b. Pure Surveillance}

A second general enforcement strategy is to undertake pure surveillance of unlawful activity. By pure surveillance, I mean government efforts to observe crime without actually participating in or encouraging it. (The surveillance may be overt, meaning the government agents are recognizable as such, or covert, meaning they are not.) Familiar examples include wiretaps, security cameras in banks and other places, uniformed or plainclothes cops patrolling to watch for crime, spies planted to eavesdrop on (but not assist) suspected criminals, or random inspections of workplaces and the like. These differ from sting operations in that government agents do not take part in crime, either as participants or as supposed victims. They simply observe, or record, the criminals' activity and then make an arrest-perhaps before the crime has been completed, as when the police overhear a bank robbery plot and then wait for the robbers at the bank, arresting them before they can carry out their plan.

The difference between stings and pure surveillance- between encouraging crime and merely observing it-is partly a matter of degree. In a sense, any covert police surveillance may be said to "encourage" crime because it hides the presence of the police. Concealment makes the risk of arrest seem lower, which, all else being equal, makes crime more attractive. A driver is more likely to speed in the presence of an unmarked police car than in the presence of a blue squad car. But there remains an important difference between sting operations and pure surveillance: in a sting, police agents take some measure to encourage crime beyond simply concealing their presence from the target. They also put out some sort of bait.

The potential advantage of using bait-rather than just relying on pure surveillance-is that it is generally easier to catch offenders with a lower expenditure of resources and with less infringement of privacy. Consider a graft case. The police hear a rumor that certain officials are taking bribes. 
One way to investigate the rumor would be to watch the officials very closely-eavesdrop on their meetings, tap their phones, read their mail, examine their bank records, and so on. ${ }^{21} \mathrm{~A}$ much simpler approach would be to have an undercover agent offer them each a bribe. The latter course intrudes less on the innocent and is less labor intensive than the former; it may also be more effective in rooting out corruption.

This point holds quite generally. The problem is no different from catching mice: if mice are lurking behind the walls of a house, it is easier to catch them by putting out baited traps than by dismantling the walls to search for them. Just so with offenders whose actions or identities are not readily observable to the authorities. Luring them into committing their crimes in the open may be far preferable, in terms of both protecting privacy and conserving law enforcement resources, to the types of passive surveillance necessary to yield a comparable chance of accurate conviction.

\section{The Problem of Entrapment}

So sting operations have substantial potential advantages over their major alternatives. Yet they pose problems of their own. The great danger of sting operations is that they may lure generally law-abiding individuals into committing offenses they otherwise would not commit. Consider the case of an individual who, targeted in a sting operation, is somehow talked into committing a crime. Had the agents left him alone, he never would have done anything unlawful, then or at any other time. Assume, for purposes of analysis, that this is known with certainty. Does it make sense to punish him for a crime the police have persuaded him to commit?

One polar position would have it that such an individual should never be convicted because the police have no business stirring up crime. There is already more than enough crime in our society without the police adding to it, and it invites trouble for the police to involve themselves in instigating crime. For example, sting operations often require the police to get mixed up with, indeed to hire, professional crooks to set traps for unwary criminals; that is the only way to get the trust of the targets. This blending of functions, in which the police befriend and employ people who belong behind bars, invites corruption $^{22}$ and blackmail, depletes the symbolic value of the law, and sullies the courts who are asked to put their stamp of approval on it. ${ }^{23}$ Courts have

21. I leave aside the question whether these measures would be constitutional.

22. Corrupt cops sometimes commit crimes and then claim it was just a sting operation. A related problem is that a cop may induce an individual to commit a crime caught on tape and extort money to keep it secret.

23. An early statement of this position:

Some courts have gone a great way in giving encouragement to detectives, in some very questionable methods adopted by them to discover the guilt of criminals; but they have not yet gone so far, and I trust never will, as to lend aid or encouragement to officers who may, under a mistaken sense of 
spoken of the judiciary's need to "protect itself and the government from such prostitution of the criminal law." 24 The problem with this polar position is that it ignores the difficulties raised by the alternative law enforcement methods canvassed above.

The opposite polar position would be that the sting victim should be punished like any other offender. What matters, it might be said, is that he broke the law, not who his accomplices were. He would not be acquitted if it had been an ordinary civilian who talked him into committing his crime. Why should we care that it was a cop (or someone working for the cops) who talked him into it? This was the position taken in some early judicial decisions. In one early New York case, the court thought it immaterial that the police had lured the defendant into the bribery scheme he was convicted of. "We are asked to protect the defendant, not because he is innocent, but because a zealous public officer . . . held out a bait. The courts do not look to see who held out the bait, but to see who took it."25

This second polar position raises evident difficulties. To begin with, it serves no real law enforcement goals for the authorities to set traps for individuals who would comply with the law if let alone by the authorities. Punishing these individuals, or threatening them with punishment, will not improve their behavior; by assumption, they are otherwise law-abiding. Punishing them is counterproductive, because resources are dissipated on harmless individuals instead of being concentrated on those who pose a genuine criminal threat. ${ }^{26}$

Also, setting traps for the law-abiding creates a great potential for abuse of governmental power. Police officials could lure their enemies into commit-

duty, encourage and assist parties to commit crime, in order that they may arrest and have them punished for so doing. . . . Desire to commit crime and opportunities for the commission thereof would seem sufficiently general and numerous, and no special efforts would seem necessary in the way of encouragement or assistance in that direction.

Saunders v. People, 38 Mich. 218, 222 (1878) (Marston, J., concurring).

24. Sorrells v. United States, 287 U.S. 435, 457 (1932) (Roberts, J., concurring).

25. People v. Mills, 178 N.Y. 274, 289 (1904). See also Bd. of Comm'rs v. Backus, 29 How. Pr. 33 (N.Y. Sup. Ct. 1864):

[T] he allegation of the defendant would be but the repetition of the plea as ancient as the world, and first interposed in Paradise: "The serpent beguiled me and I did eat." That defence was overruled by the great Lawgiver, and whatever estimate we may form, or whatever judgment pass upon the character or conduct of the tempter, this plea has never since availed to shield crime or give indemnity to the culprit, and it is safe to say that under any code of civilized, not to say christian [sic] ethics, it never will.

This position, which allowed no defense of entrapment, did not survive the nineteenth century.

26. Judge Posner made this point in United States v. Kaminski, 703 F.2d 1004, 1010 (7th Cir. 1983) (concurring opinion). 
ting crimes, and then use these as a pretext for jailing them. This is a common technique by which authoritarian governments get rid of dissident groups. ("Just give us a person-and we'll create the case.") ${ }^{27}$ In this country as well, government agencies have on occasion resorted to this strategy in order to jail or blackmail political opponents. ${ }^{28}$

Finally, aside from wasted enforcement resources and the dangers of abuse, it is socially costly to have the police stirring up and then punishing crimes. The stirred-up crime itself may cause harm: usually the police try to make an arrest before any real harm is done, but there is no guarantee they will succeed. For example, if a police officer poses as a drug dealer, he may inspire a customer to mug a bystander for drug money. ${ }^{29}$ The punishment, too, is costly; if the sting victim would not have committed the crime without police inducement, locking him up is needlessly destructive.

The defense of "entrapment" represents courts' response--a sort of middle course-between the polar positions just described. ${ }^{30}$ This doctrine, or more properly cluster of doctrines, is a complex amalgam of judge-made common law, statutes, and constitutional law. If a defendant is proven guilty of all of the elements of an offense, he may nonetheless raise the defense of entrapment if, under specified circumstances, he was lured by the police (or an agent working at police behest) into committing his crime. Because it is generally not rooted in federal constitutional law, each state (as well as the federal judiciary for federal prosecutions) has its own entrapment rules. ${ }^{31}$

Broadly speaking, the defense is designed to prevent the police from luring individuals into committing crimes they would probably not otherwise

27. AleKSANDR I. SOlZhenitsyn, THE GULAg ARChipelago 1918-1956, at 146 (Thomas P. Whitney trans., 1973).

28. See MARX, supra note 3, at 63-65, for examples and discussion of this problem. To mitigate this type of danger, some have proposed that sting operations be limited to cases in which there is a reasonable suspicion or probable cause that the target is already engaged in criminal behavior. See, e.g., Maura F.J. Whelan, Comment, Lead Us Not into (Unwarranted) Temptation: A Proposal to Replace the Entrapment Defense with a Reasonable-suspicion Requirement, 133 U. PA. L. REV. 1193 (1985). The proposal has generally been rejected, though it was adopted by the Nevada Supreme Court in Shrader v. State, 706 P.2d 834 (Nev. 1985), overruled by Foster v. State, 13 P.3d 61 (Nev. 2000).

29. In one study, there was evidence that in creating a fencing operation for stolen goods, a police sting encouraged more thefts. See Robert H. Langworthy, Do Stings Control Crime? An Evaluation of a Police Fencing Operation, 6 JUST. Q. 27 (1989).

30. On the historical development of the doctrine, see Michael A. DeFeo, Entrapment as a Defense to Criminal Responsibility: Its History, Theory and Application, 1 U.S.F. L. REV. 243 (1967).

31. Sometimes a defendant may establish that the government's conduct was so outrageous that it violated the federal due process clause, but this is exceedingly unusual. Virtually all entrapment cases are based on common law or (in the case of some states) on statutes. 
commit. In spite of its name, the entrapment doctrine does not bar all police traps: the government is sometimes permitted to lure individuals into committing crimes and then punish them for those crimes. The crux of the entrapment doctrine is that individuals may only be convicted for falling into government traps if they were, in some sense, ready or likely to commit crimes without government encouragement. Interestingly, the doctrine appears to be limited to the criminal context; it does not seem to be applied to civil law enforcement or enforcement of private organizational rules such as employment regulations. ${ }^{32}$

Two basic legal formulations of, or approaches to, the entrapment doctrine are in currency. One approach focuses on the proclivities of the individual sting victim: courts ask whether this particular defendant was likely to, or inclined to, commit the offense if the police had not lured him into doing so. Typically, this formula turns on the defendant's state of mind before the sting. If he was not "predisposed" (or "ready and willing") to commit the crime before being lured into doing so, he cannot be convicted of the resulting offense. ${ }^{33}$ This formulation is conventionally called the "subjective" approach to entrapment. Under this approach, the court examines the particular defendant's reputation, criminal record, and so forth.

The second approach focuses not on the propensities of the individual defendant, but rather on the bait put out for him by the police. It asks whether the bait is likely, in general, to lure otherwise-innocent people into committing crimes. An influential statement of this approach is contained in the Model Penal Code: entrapment occurs when a police agent "encourages another person to [commit an offense] by ... employing methods of persuasion or inducement that create a substantial risk that such an offense will be committed by persons other than those who are ready to commit it." ${ }^{34}$ This is commonly referred to as the "objective" test for entrapment because it looks at a hypothetical average person's response to the bait used by the police. ${ }^{35}$

32. See United States v. Hollingsworth, 27 F.3d 1196, 1203 (7th Cir. 1994) (en banc); Grasso v. Forrest Edward Employment Servs., No. 01 CIV. 3263(AKH), 2002 WL 989528, at *9 (S.D.N.Y. May 15, 2002) ("[E]ntrapment is a defense only to criminal charges and has no applicability as an affirmative civil claim."); Vassar v. Baxter Healthcare Corp., No. 4:93CV97BO, 1995 WL 1945546, at *5 (N.D. Miss. June 29,1995 ) (suit alleging entrapment of employee by employer does not state a claim).

33. See, for example, Jacobson v. United States, 503 U.S. 540 (1992), in which a government front organization, acting a child pornography operation, embarked on a 26-month campaign (eventually successful) to get the defendant to buy child pornography. Id. at 543-46. The campaign included literature suggesting that ownership of such material was protected by the First Amendment. Id. at 543-44. The Court held that the defendant should have been acquitted on entrapment grounds, because the government had to talk him into buying the material. Id. at 548-54.

34. MOdEL PENAL CODE $§ 2.13$ (1962) (emphasis added).

35. Thus, under the objective test, the defendant may be acquitted even if the bait used was of the type that might attract people who were not predisposed. But under 
Under this approach, the court does not care whether the defendant was or was not personally predisposed to commit the crime (hence his reputation and the like are irrelevant); it cares only whether the method used against him is likely to ensnare people who are not criminally predisposed.

From the beginning, modern entrapment law has been an intricate patchwork of these two general approaches. The "subjective" approach is the predominant one in this country. ${ }^{36} \mathrm{~A}$ few jurisdictions make exclusive use of the "objective" approach, which also comes in different versions. ${ }^{37}$ Most jurisdictions use both approaches, in varying blends. ${ }^{38}$ Jurisdictions also differ on the appropriate standard of proof in entrapment cases. ${ }^{39}$ These matters remain in flux. ${ }^{40}$

This complex state of affairs is one indication of the difficulty that courts, and other regulators of police activity, have in defining the proper limits of sting operations. ${ }^{41}$ The problem, as one Supreme Court opinion put it, is that "a line must be drawn between the trap for the unwary innocent and the trap for the unwary criminal."42 Where does the right line lie? Our purpose in what follows is to examine the general structure of this problem in light of the informational and behavioral purposes stings may serve.

the subjective test, the potential effect on other hypothetical people is irrelevant; all that matters is whether he himself was predisposed.

36. See Paul Marcus, The EnTRAPMEnT Defense 52 (2d ed. 1995).

37. See id. at 39-43.

38. Some acquit the defendant if entrapment is established under either the subjective or objective test. See id. at 44-47. Others acquit only if entrapment is established under both tests. See id.

39. Everyone agrees that the defendant's crime must be proved beyond a reasonable doubt. But if the defendant says he was entrapped into committing the crime by the police, by what standard is the entrapment issue judged? Many jurisdictions, including the federal courts, say that once the defendant establishes that he was induced by the police to commit the offense, the state must prove beyond a reasonable doubt that he was predisposed to commit the crime in question. But many states opt for lower standards. See, e.g., State v. Hammeren, 655 N.W.2d 707, 709 (N.D. 2003) (defendant must prove all elements of entrapment defense by a preponderance of the evidence); State v. Grubb, 725 A.2d 707, 711 (N.J. Super. Ct. App. Div. 1999) ("State must disprove ... entrapment by 'clear and convincing' evidence.").

40. Legislatures and police organizations have also struggled with the problem, often adopting guidelines that go beyond the requirements set forth by the courts. See, e.g., UNITED STATES DEP'T OF JUSTICE, UNDERCOVER AND SENSITIVE OPERATIONS UNIT, ATTORNEY GENERAL'S GUIDELINES ON FBI UNDERCOVER OPERATIONS (1992), available at http://www.usdoj.gov/ag/readingroom/undercover.htm\#general (reasonable suspicion of wrongdoing is a prerequisite to use of undercover agents); SEATTLE, WASH., MUNICIPAL CODE $\$ 14.12 .020$ (2004) (prohibiting surveillance for purely political purposes).

41. Legislatures and police oversight bodies have joined the courts in struggling with the problem.

42. Sherman v. United States, 356 U.S. 369, 372 (1958) (emphasis added). 


\section{STING OPERATIONS AS AN INFORMATIONAL DEVICE}

\section{A. Informational Objectives}

Courts tend to see exposing crooks as the main justification for sting operations. An influential passage comes from the Supreme Court's first entrapment decision:

Artifice and stratagem may be employed to catch those engaged in criminal enterprises. The appropriate object of this permitted activity, frequently essential to the enforcement of the law, is to reveal the criminal design; to expose the illicit traffic, the prohibited publication, the fraudulent use of the mails, the illegal conspiracy, or other offenses, and thus to disclose the would-be violators of the law. ${ }^{43}$

This purpose-"to reveal the criminal design"-is the central theme in the case law on stings.

The case law is full of similar statements. Typical is this claim by the California Supreme Court: "The function of the enforcement officials is to investigate, not instigate, crime; to discover, not to promote, crime." ${ }^{, 44}$ Or take this remark by Judge Posner, in a case in which agents helped an arsonist set up his crime and arrested him just before he torched the building: "It is particularly difficult to catch arsonists, so if all the police were doing here was making it easier to catch an arsonist-not inducing someone to become an arsonist - they were using law enforcement resources properly and there is no occasion for judicial intervention." 45 Our focus here will be on this function of identifying likely criminals.

A note on terminology. As the italicized language above suggests, the intended targets may be law violators or would-be law violators. Many sting operations are employed to track down, or generate evidence against, active criminals. For example, agents might set up a phony trash collection business in order to attract extortion attempts from mobsters who have been threatening local businesses. Many other stings are directed against potential criminals, that is, people who may or may not have committed crime in the past, but are likely to do so in the future. Consider the cop who pretends to be an adolescent visitor to an internet site for pedophiles: he is trying to catch individuals who are inclined to prey on children, whether or not they have done so in the past.

43. Sorrells v. United States, 287 U.S. $435,441-42$ (1932) (italics added and citations omitted).

44. Patty v. Bd. of Med. Exam'rs, 107 Cal. Rptr. 473, 478-79 (Cal. 1973).

45. United States v. Kaminski, 703 F.2d 1004, 1010 (7th Cir. 1983) (Posner, J., concurring). 
I will merge these two groups-potential and actual lawbreakers-into a single category interchangeably called "criminals" or "offenders." (These terms are equivalent to the doctrinal formulations of "predisposed" or "ready and willing"; I use my terms because they produce a bit more expositional clarity.) Essentially, for purposes of the analysis to follow, the assumption is that there is a group of individuals who, left to their own devices, would likely have committed a crime (or would be predisposed to do so) independent of police involvement. Thus, a sting victim is a criminal if he would have committed the same type of offense had he never been targeted by the police. He would have had both motive and opportunity to commit a genuine crime even without the sting.

I use the term "genuine" or "independent" criminal opportunity interchangeably to mean an opportunity not created by a sting operation. So, for example, a criminal operation with no police involvement is a genuine criminal opportunity. A criminal opportunity staged by the police would be a nongenuine opportunity. There is, of course, a continuum here: an undercover agent may play a critical role, or instead merely a minor role, in a criminal operation, in which case the question arises whether the crime was genuine or a sting - that is, whether the crime would have come off without the agent's help. Consider, for example, the undercover agent who supplies hardware for a pipe bomb; perhaps a non-agent would have done the same thing, so we might consider the crime genuine.

A separate category, distinct from criminals or offenders, consists of individuals we will call "non-criminals" or "non-offenders" or "innocent." 46 These are individuals who would not have-or probably would not havecommitted the offense charged if they had not been given the opportunity provided by the government agent. ${ }^{47}$ Let me emphasize that that these individuals are not necessarily "innocent" in the ordinary sense of the word: they have, by assumption, committed the crime charged, albeit with the assistance or encouragement of an undercover agent. The only reason we refer to them as non-criminals or nonoffenders or innocent is for expositional clarity.

Of course, there is a strongly artificial element in this distinction between criminals and non-criminals. Not everyone we have branded a "criminal" seizes every genuine opportunity to commit any offense. At the same time, not everyone we have branded a non-criminal always refrains from committing a genuine offense. Even the normally law-abiding among us may sometimes succumb to temptations to criminal activity. These complications are undoubtedly evident to all.

46. Again, these terms are intended to be equivalent to the doctrinal references to those who are not "predisposed" or "ready and willing" to commit crime.

47. For the most recent Supreme Court pronouncement on the subject, see Jacobson v. United States, 503 U.S. 540 (1992), in which the Court ordered the defendant acquitted after a government front organizations spent years talking him into buying illegal child pornography. 
Nonetheless, it is analytically useful to draw a rough distinction between criminals and non-criminals. There are those who are far more likely to seize criminal opportunities than others. Our interest here is in using baits to identify these individuals. The authorities want to identify (catch and/or gather evidence against) criminals. Our assumption in what follows is that this is an appropriate state objective. ${ }^{48}$ As noted above, the authorities' ultimate objective is not necessarily to punish these individuals; the objective may be to build a case against them, which can be used to secure their cooperation in catching bigger fish.

The theory behind using a sting for informational purposes is that it operates as a test. If the target committed this staged crime, the thinking goes, he is likely to commit real crimes as well. ${ }^{49}$ More precisely, in committing the crime set up by the police, the target signals that he is likely to commit, or attempt, independent crimes in which the police are not involved. If the internet pedophile arranges a secret meeting with a police decoy pretending to be a child, he is likely to do or have done the same with real children.

But how likely, as a positive matter? This is the critical question if the sting is being used for informational purposes. The police have set a trap designed to catch a criminal. What are the chances that the defendant caught in the trap is in fact a criminal? Each decision maker in the defendant's casethe prosecutor deciding what charges to bring, the jury deciding whether to convict, and the judge deciding on a sentence-may have to face this problem.

\section{B. A Bayesian Framework}

The problem is one of Bayesian inference. The decision maker knows that the defendant rose to the bait put out by the police. The decision maker also has some background data, or beliefs, about the defendant's likelihood of being a criminal. From these bits of information the decision maker tries to judge the overall likelihood that the defendant is a criminal. Expressed in odds form, ${ }^{50}$ that overall likelihood is equal to

48. Some commentators are troubled by this notion of using stings to catch individuals who would commit, but have not (been proven to have) committed, any crime. See, e.g., Jonathan C. Carlson, The Act Requirement and the Foundations of the Entrapment Defense, 73 VA. L. REV. 1011 (1987).

49. Courts tend, however, to disapprove of "sentencing entrapment," in which the agents talk the target into dealing with a larger quantity of drugs than he had contemplated, in order to put him in a higher sentencing category. See, e.g., United States v. Staufer, 38 F.3d 1103 (9th Cir 1994) (defendant was predisposed to sell drugs, so not entitled to acquittal on entrapment grounds; however, he was entitled to a lesser sentence because the agents convinced him to substantially increase the amount of drugs he was predisposed to sell).

50 . Odds and probability are related as follows. If $p$ is the probability of an event, then the corresponding odds are $p /(1-p)$ to 1 . For example, if the probability of 


\section{background odds $\times$ sting diagnosticity.}

Thus, for example, if the background odds that he is a criminal are 2 to 1 , and the sting's diagnosticity is 5 to 1 , then the overall odds that the defendant is a criminal are 10 to 1 . Let us consider the meaning of each of these terms.

\section{Background Odds}

"Background" here refers to information other than the fact that (or manner in which) he took the bait. ${ }^{51}$ Background odds of 2 to 1 means that, looking at the background information alone (that is, not knowing whether he took the bait), the decision maker would conclude that the odds are 2 to 1 that the defendant is a criminal. ${ }^{52}$ The information on which these odds are based may be gathered before the sting; often the police will investigate a target and gather incriminating information before holding out a bait for him. But it may be gathered after the fact; for example, following a drug sting, the police may find drug paraphernalia at the target's house. ${ }^{53}$

The background odds are derived from whatever information is made available to the decision maker concerning the defendant's likelihood of being a criminal. It might be statements that the defendant makes to police or third parties, either before or after the sting. It might be earlier arrests or convictions for similar offenses. It might be other evidence of the defendant's character or criminal propensities. The jury is frequently permitted to hear such evidence in entrapment cases, subject to familiar limits on admissibility. ${ }^{54}$ And even if the jury does not hear it, the prosecutor may hear it and take it into account when charging; likewise the judge, when sentencing.

the event is .75 , then the odds are $(.75) /(.25)=3$ to 1 . This relation is readily derived from Bayes' theorem concerning probabilities.

51. The manner in which the defendant takes the bait (eagerly or reluctantly) obviously may furnish some information about whether he is a criminal. But we treat this as part of the diagnostic value of the sting, not as background information.

52. In Bayesian language, the background odds are the "priors", that is, the anterior odds that the defendant is a criminal. I avoid the "priors" terminology in the text to prevent the misleading impression that the information is necessarily gathered before the sting operation. "Priors" is also confusing because it is slang for prior offenses.

53. The target's taking the bait may tip off the police that they should investigate him further. Also, it may give them probable cause to search his premises.

54. See, e.g., United States v. Van Horn, 277 F.3d 48 (1st Cir. 2002). Federal and state rules of evidence prohibit the admission of character evidence, or of prior bad acts, to prove action in conformity therewith. See FED. R. EVID. 404; state rules are roughly identical. That rule generally does not apply to entrapment cases, where the issue is not whether the defendant committed the crime, but whether he was predisposed to do so. See, e.g., United States v. Neville, 82 F.3d 1101, 1107-08 (D.C. Cir. 1996). 
The background odds for a given defendant may or may not be different from those of the general population. In some instances, there may be little specific information one way or the other about the defendant's likelihood of committing crimes. If so, the relevant background odds are simply those of the average member of the population. In other instances, there may be information that makes the defendant stand out from the crowd, as less, or more, law-abiding than average. In such cases, the background odds are correspondingly higher or lower than average.

\section{Sting Diagnosticity}

This refers to the sting's effectiveness as a test. Diagnosticity is, in essence, the ratio of true positives to false positives. For our purposes, taking the bait is a "positive," that is, a possible signal that the target is a criminal. A true positive occurs when the bait is taken by a criminal; a false positive occurs when the bait is taken by a non-criminal. Sting diagnosticity of 5 to 1 means that the bait is five times more likely to be taken by a criminal than by a non-criminal.

The signaling value of different stings can vary enormously. Sometimes the police devise a trap that only a criminal can fall into. Consider the case of an undercover cop who approaches a target and offers to buy, right then and there, a substantial quantity of cocaine. The target agrees and pulls out of his pocket a large quantity of the drug, packaged for sale. The target's behavior reveals him to be a drug dealer; presumably he is likely to sell to people other than the cop. By asking for the drugs to be produced on the spot, the cop has screened out non-drug dealers, who are unlikely to be walking around with large packages of cocaine. The one who falls into the trap sends a strong signal that he is a criminal.

Other stings generate much weaker signals. Consider a target offered an unusually tempting opportunity, one she never would have encountered in real life. Suppose the target is given a chance to steal a large amount of cash at little apparent risk. A crook-someone who would commit other theftsmay be more likely than an honest person to take this bait. But an otherwise honest person might well take it, though he never would have committed theft without this once-in-a-lifetime opportunity. This sting thus provides at best a modest signal that the sting victim is a real thief. ${ }^{55}$

55. Real-life examples are plentiful. A target was offered 20 kilos of cocaine at a colossal discount, having been told that the agent (supposedly an airline worker) had found the drugs in some cargo. State v. Anders, 596 So. 2d 463, 464 (Fla. Dist. Ct. App. 1992). The target had never engaged in trafficking, but was talked into it based on the huge profit he would make. Id. at 465 . The court held that the target was entrapped. Id. at 468 . 
Still other stings may have no signaling value. ${ }^{56}$ If the police agent makes an "offer that cannot be refused," then the target reveals nothing about himself by accepting. This is especially likely to happen when the police use criminal informants to carry out stings. The informant, hoping to earn either money or leniency from the police, ${ }^{57}$ sets out to arrange as many drug deals as he can that will lead to arrests. He begs his friends to buy or sell drugs for him, claiming that he is desperately ill, that he owes money to dangerous people, etc.; when his friends fall for it, they are arrested. ${ }^{58}$ Obviously, a sting of this type is not very probative of the target's criminal tendencies. Even a non-criminal, who would not otherwise consider buying or selling drugs, will succumb if enough pressure is put on him.

Another sting with little signaling value is one in which threats are used to secure the target's participation. ${ }^{59}$ Indeed, a sting of this nature may have negative signaling value, tending to suggest that the sting victim is a noncriminal. In numerous cases, the undercover agent starts by exerting mild pressure on the target, pleading with him for help; when the target demurs, the agent badgers or threatens him until he finally gives in. Often the target is a recovering addict, trying hard to stay clean. ${ }^{60}$ Here, the target's reaction to the sting - taking the bait only very reluctantly-may indicate that he was not likely to commit the crime in the absence of the agent's blandishments.

For this reason, a sting may tend to exonerate rather than incriminate, even though the target took the bait. Of course, apparent reluctance is not necessarily exonerating. Professional crooks often feign reluctance when approached to do a "job" (precisely in order to ward off stings) before finally accepting the offer. If there is strong background evidence, the decision maker may yet conclude that the overall odds are high that the target is a criminal. But that may be in spite of, not because of, the target's reaction to the sting.

56. It has zero signaling value if diagnosticity is 1 to 1 . It gives no more information than flipping a coin.

57. In some instances, the informant is a criminal defendant, and has been promised leniency if he arranges a certain quota of drug deals that lead to arrests. In other instances, the informant is paid in cash-either on a per-arrest basis, or as a percentage of the dollar amount of the drug sales. Courts generally throw out convictions that are the product of such contingency fees. See State v. Glosson, 462 So. 2d 1082 (Fla. 1985); State v. Florez, 636 A.2d 1040 (N.J. 1994).

58. See United States v. McLernon, 746 F.2d 1098 (6th Cir. 1984) (agent tells his friend that the mob will kill him unless the target gets him some drugs).

59. An instance is Robichaud v. State, 658 So. 2d 166 (Fla. Dist. Ct. App. 1995), in which an undercover agent asked the target to obtain cocaine "to alleviate pain he suffered from cancer and chemotherapy treatments." Id. at 167. The target had no previous experience with drugs. Id. at 168 . When the target demurred, the agent claimed that that he had mob connections, "his boys," who would "take care of" the target if he didn't obtain the drugs. Id.

60. See Wagner v. State, 467 S.E.2d 385 (Ga. Ct. App. 1996), for such a case. 


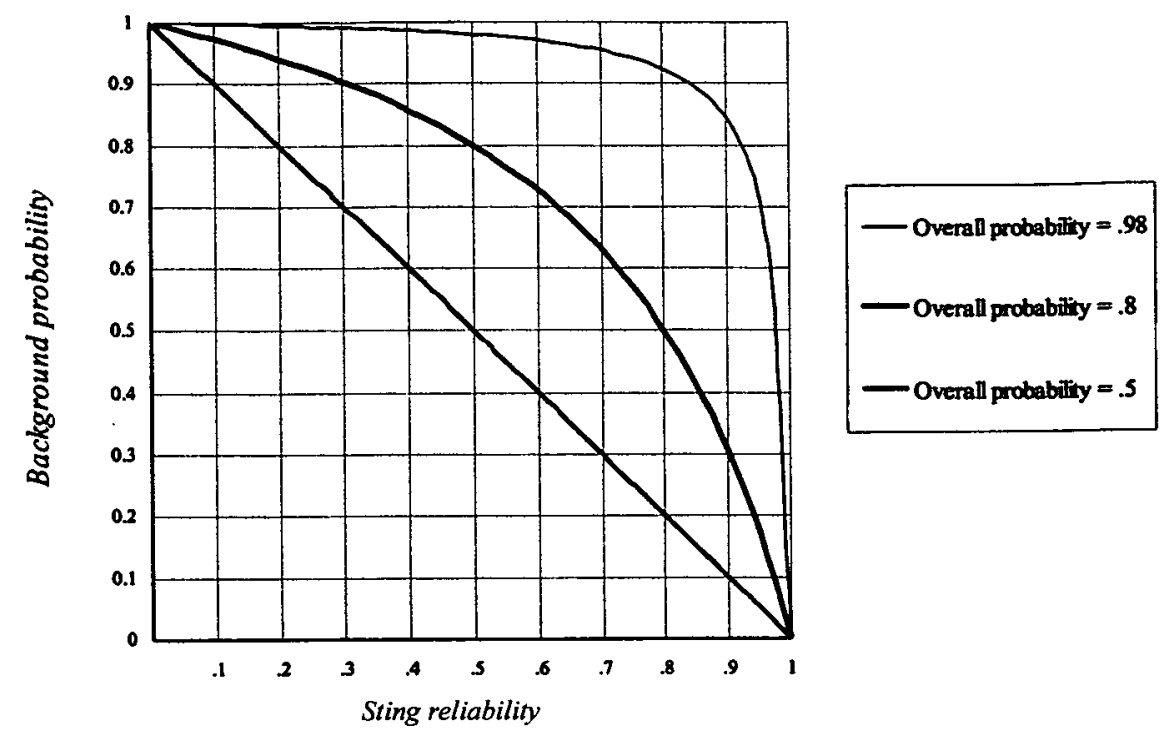

Figure 1 - Overall probability that a sting victim would commit independent offense, given background evidence and sting reliability.

\section{Applying the Framework}

Figure 1 gives an intuitively accessible illustration of the relation between sting reliability and background information. ${ }^{61}$ It shows the combinations of these two factors necessary to yield a given level of confidence that the victim of a sting would commit a similar crime independently of police involvement.

The horizontal axis, "sting reliability," is a measure of the sting's accuracy rate in identifying criminals: it indicates what fraction of positives are true positives. ${ }^{62} \mathrm{~A}$ number greater than .5 means that the sting has some signaling value: criminals are more likely to fall for it than non-criminals. A number less than .5 means the sting has negative signaling value: it is more likely to catch non-criminals than criminals. A value of .5 means it has no signaling value.

The vertical axis refers to the background probability that the sting victim is a criminal. This is the likelihood drawn from the available information other than the target's reaction to the sting, as discussed above. It is the same as the background odds, except described in terms of probability rather than

61. The derivation of the figure is explained in the Appendix.

62. If $a$ is the probability that a criminal will fall into the trap, and $b$ the probability that a non-criminal will fall into it, the horizontal axis represents the scale $a /(a+b)$. 
odds. This representation shows the structure of different possible entrapment rules.

\section{Standards of Proof}

The three curves-which were chosen more or less arbitrarily-in the figure represent the combinations of sting reliability and background probability that establish three chosen levels of confidence that the sting victim is a criminal. ${ }^{63}$ So, for example, a combination of .3 sting reliability and .9 background probability-coordinates $(.3, .9)$ in the figure-is on the middle curve, meaning that the overall probability is .8 that the sting victim is a criminal.

The chosen curves are meant to approximate the different standards of proof often employed in entrapment cases. Many jurisdictions, including the federal courts, require the state to shoulder a burden of proof beyond a reasonable doubt on the entrapment issue. ${ }^{64}$ Assuming, for purposes of analysis, that reasonable doubt exists if there is at least a two percent chance the defendant is a non-criminal, ${ }^{65}$ a defendant cannot be convicted under this standard unless his case falls somewhere outside the top curve on the question of whether he would commit the crime independently. ${ }^{66}$

Other jurisdictions put lighter burdens on the state. Some require proof only by a preponderance of the evidence on the issue of entrapment; this would mean the defendant could not be convicted unless his case fell somewhere just above the diagonal line. Some require proof by clear and convincing evidence, which presumably lies somewhere between the preponderance and reasonable-doubt standards. Perhaps the middle curve in the figure is an approximation of this standard.

63. These curves were selected because I conjecture they correspond roughly to the three most common standards of proof in entrapment cases below. Of course, a decision maker (perhaps a national security agency) might want to use a still lower standard of proof-say, 20 percent-in deciding whether to retain an employee who succumbs to a sting, in which case the curve would be convex rather than concave in shape. The curve for a .20 standard of proof would be the mirror image of the .80 curve, reflected across the diagonal line.

64. See supra note 39.

65. Some put the numerical line higher or lower. For discussion of the issue, see Alexander Volokh, $N$ Guilty Men, 146 U. PA. L. REV. 173 (1997). Most courts avoid attempting to quantify the legal standard. For an economic analysis of the costs of judicial error, see Louis Kaplow, The Value of Accuracy in Adjudication: An Economic Analysis, 23 J. LEGAL STUD. 307 (1994).

66. Again, we are treating as roughly synonymous the question whether the defendant would have committed the question the courts focus on-the defendant's "predisposition"-and the question whether the defendant is a criminal. The analysis can easily be adapted to either formulation. 


\section{Subjective vs. Objective Approaches}

We noted above that the "subjective" approach to entrapment, which asks whether the particular defendant caught in a sting would have committed the crime on his own-or more precisely, was "predisposed" to commit the crime-is dominant in the United States. The implementation of this approach tracks, in broad outline, the Bayesian model sketched here. In applying the formula, the courts consider the probative value of the sting itself, that is, what it says about his criminal propensities. They also look at background information bearing on his criminal leanings, such as his actions or statements on other occasions. ${ }^{67}$

In contrast is the "objective" approach, which asks whether the tricks or inducements used by the police are likely to lure non-criminals into committing offenses. To courts that use this approach, the likely actions or predispositions of the person(s) actually caught in the trap are irrelevant; ${ }^{68}$ what matters is how the ordinary law-abiding person would respond to the bait offered by the agent. In effect, this approach focuses exclusively on the diagnostic value of the sting, ignoring background information about the target. It considers only where a case falls on the horizontal axis of figure 1 .

A typical illustration of the difference here is found in the courts' treatment of so-called supply-and-buy, or take-back, drug stings: one agent furnishes the target with a stash of narcotics, another agent talks the target into selling part of it, and he is then arrested for peddling drugs. Most courts seem to agree that these stings generally have little if any probative value. With the government playing both supplier and buyer, the operation scarcely signals, in the view of the courts, that the target would sell drugs on his own. ${ }^{69}$

Yet the courts treat the victims of such stings in very different ways. Some courts (following the "subjective" approach), acknowledge that supplyand-buy stings are unreliable, but they look at the other evidence in the case. If there is strong background evidence that the sting victim is a drug dealer, they will allow a conviction. ${ }^{70}$ Other courts, employing the "objective" approach, categorically forbid convictions based on supply-and-buy stings because they see too great a risk that the stings will yield false positives-if not

67. See, e.g., United States v. Ramsey, 165 F.3d 980, 985 (D.C. Cir. 1999) (finding predisposition based on prior convictions, tape recorded conversations, and the eagerness with which the defendant took the bait). The type of evidence admitted for this purpose is comparable to the evidence judges consider in sentencing a convicted defendant in ordinary cases.

68. See, e.g., People v. Munoz, No. E029685, 2002 WL 31032872, at *5 (Cal. Ct. App. Sept. 12, 2002) ("In applying the objective test of entrapment, a defendant's character, predisposition, and subjective intent are irrelevant.").

69. Often the target is an addict who has bought the drugs from the first agent for his own use. The second agent usually has to pressure him into selling.

70. United States v. Brooks, 215 F.3d 842 (8th Cir. 2000), references this principle. 
in the particular defendant's case, then in the run of cases. In these courts, acquittal is automatic; it does not matter how damning the background evidence is in the particular case. ${ }^{71}$

The latter courts, which acquit regardless of the background evidence, are not behaving as "good" Bayesians. Nonetheless, it is easy to sympathize with their position, at least in principle. They see supply-and-buy stings as providing next to no information about the target. If the proper purpose of sting operations is to help identify criminals, then-these courts might think-a defendant should not be convicted on the basis of a sting that contributes nothing on this issue. Perhaps they are wrong in their view that supply-and-buy operations lack informational value. But if they were correct in holding that view, it would make sense not to permit their use when the objective of stings is to generate information.

This reasoning implies that a defendant should not be convicted in a sting unless the sting's reliability is greater than .5 , that is, on the right-hand side of the figure. Only in the right-hand region of the figure does the sting have any diagnostic value. In the left-hand region, a target who takes the bait does not thereby signal that he is a criminal; instead, he signals the opposite. This may be the logic behind the stance, taken by many courts, that a defendant cannot be convicted based on an unreliable trap, no matter how strong the background evidence is.

\section{Sting Operations as a DeterRent DeVice}

\section{A. Deterrence Objectives}

Let us turn to the use of sting operations as a deterrent device. A natural effect of permitting covert police activity-and publicizing the fact-is to make individuals fear that they may be under surveillance without knowing it. Obviously this policy is counterproductive if taken too far; civil society wilts if everyone suspects everyone else of being a government spy or agent provocateur. ${ }^{72}$ But properly channeled, the uncertainty created by covert police activities can have very desirable deterrent properties. If would-be offenders are worried that an apparently attractive criminal opportunity is really a trap, they may decide to walk away from it. ${ }^{73}$

71. See, e.g., State v. Overmann, 220 N.W.2d 914, 917 (Iowa 1974); State v. Johnson, 268 N.W.2d 613 (S.D. 1978). These courts will allow government agents to be on the supply end or the buy end, but not both.

72. North Korea and the former East Germany come readily to mind.

73. Refraining from crime is only one possible response. Another is to commit crime but proceed more carefully (mobsters might pat each other down to check for wires). And there will also be a substitution effect, toward crimes less susceptible to covert surveillance. 
This is often just the effect sought by the authorities. The police may want a criminal gang to believe that it has been infiltrated by government moles. ${ }^{74}$ Likewise, the police may encourage would-be offenders to believe that some of their prospective victims are really police decoys, and that their crimes will be caught on camera. ${ }^{75}$ The theory behind punishing sting victims, on this account, is not that they have revealed themselves to be crooks. Perhaps they have, perhaps not. Rather, the theory is to make people afraid to be crooks. If stings are believed to be pervasive enough, then would-be offenders will shy away from real criminal opportunities, for fear that they are stings.

Notice that the measure of success is quite distinct for informational stings and deterrent stings. With informational stings, the hope is to separate the crooks from the law-abiding. A key mark of success is that would-be crooks are getting caught in traps; the more caught, the better. Deterrent stings are another matter. The hope is to make crooks law-abiding. A key mark of success is that would-be crooks are not getting caught in traps because they have been frightened away from committing crimes. ${ }^{76}$ They steer clear not only of stings but of real criminal opportunities as well because they cannot tell them apart.

\section{B. A "Lemons" Framework}

To examine the deterrent use of stings, let us bracket, to the extent possible, the information-gathering function considered in the last Section. We will assume here that the authorities' objective is not to identify criminals (that is, those who are likely to commit independent crimes), but rather to discourage crime. Any information a sting reveals about its targets is, we will assume, purely incidental to the main goal of deterring crime. ${ }^{77}$

When deterrence is the objective, the government creates something akin to the well-known market for lemons. ${ }^{78}$ The government introduces lemons-phony criminal opportunities-that resemble the genuine article. To the would-be offender, the risk of being caught in a trap makes it costlier to seize apparent opportunities for crime. He may therefore turn away genuine opportunities that would otherwise attract him. Just as the presence of lemons in the auto market discourages the sale of even good cars, the presence of lemons in

74. The government faces a tradeoff here. People suspected of being moles may be in grave danger.

75. For example, the police will announce that a certain number of pedestrians in dangerous intersections are really cops ready to arrest reckless drivers.

76. Of course, the reason some are not being caught in traps is that they are taking care to avoid them.

77. The overlap occurs when the government publicizes its successful sting of, say, operators of a child pornography web site.

78. See George A. Akerlof, The Market for "Lemons": Quality Uncertainty and the Market Mechanism, 84 Q.J. ECON. 488 (1970). 
the market for crime discourages genuine criminal transactions. If the sting totally succeeds, the market for real criminal opportunities "unravels," driving criminals into other activities. For example, if there were enough phony buyers of narcotics on the street, the price of drugs would rise so high that genuine buyers would disappear. ${ }^{79}$

This occurs under the following general conditions. Suppose that an individual gets an apparent criminal opportunity: someone offers to sell him a substance (drugs, ivory, enriched uranium) whose purchase is unlawful. The offer may be genuine or a sting. The individual will refrain from accepting the offer if the following holds:

$$
\text { probability of sting }>\frac{\text { expected gain if genuine }}{\text { expected penalty if sting }}
$$

The "probability of sting" term refers to the chance that the offer is a sting rather than genuine. Parties to criminal transactions may fear that they are dealing with government agents. Governments can take steps to encourage this fear, sometimes even spreading false or exaggerated rumors of the existence of sting operations. Such rumors are believable because they are sometimes true.

The "expected gain if genuine" refers to the individual's anticipated profit from the crime if the opportunity is not a sting. It includes not only the expected gain if he gets away with it, but any expected punishment from possible ex post detection. The expected gain from genuine crime obviously varies across individuals. For some, the chance to buy an illegal substance at price $\$ X$ will be very attractive, if the opportunity is genuine. For others, such an offer is completely unattractive. The threat of a sting may not even be necessary to dissuade them from accepting.

The "expected penalty if sting" refers to the anticipated punishment if the seller is an undercover agent. Normally this would be a fine or imprisonment, though sometimes the state resorts to public exposure instead. The prospect of being caught on tape committing a crime, and then seeing the tape publicly released, may alone be a substantial deterrent for many. ${ }^{80}$

This framework can easily be adapted to represent non-transactional stings involving violent crimes and the like. "Lemons" can take the form, for example, of cops posing as prospective victims for muggers, peddlers of worthless securities, or pedophiles. The framework can also easily be adapted to cover civil offenses, such as race discrimination in housing, and can be adapted to cover stings used by private organizations to deter dishonest em-

79. This has obviously not yet occurred in the narcotics market.

80. In prostitution stings, the police have sometimes limited themselves to releasing names or televised recordings of individuals caught soliciting sex from an undercover agent. 
ployees and the like. The above inequality captures the conditions in all of these cases.

\section{Applying the Framework}

The problem facing the authorities is to ensure that the above inequality holds for the genuine opportunities encountered by an individual. If it succeeds, the individual will turn away not only staged opportunities, but real ones as well. To go about its task, the government can try to raise the lefthand side or lower the right-hand side of the inequality, or both. ${ }^{81}$ Our focus here will be on the left-hand side, the probability of a sting.

\section{Sting Types}

The inequality implies that the behavior of agents must mimic the behavior of genuine sellers. This is true not only because phony opportunities must be unrecognizable as such (many stings fail because the target smells a rat). It is true for a less obvious reason: genuine opportunities must also be unrecognizable as such if the purpose of the sting is to deter genuine sales. The government cannot permit genuine sellers to have a "trademark" or distinguishing feature that enables the buyer to know he is safe from a trap.

In any lemons market, the buyer will look for credible signs that he is buying from a genuine seller. One such signal may lie in the seller's actions. If certain behavior is prohibited for undercover agents, then anyone who displays the behavior signals that he is not an agent. The government has to prevent signaling of this type, and the only way for it to do so is to have its agents copy the actions of genuine sellers.

An example of government failure in this respect is police department guidelines that used to prohibit agents from initiating criminal transactions; such guidelines required police to be solicited by the target instead. ${ }^{82}$ Experienced criminals, aware of this policy, used it as a screening device to make sure they were not dealing with undercover cops. They waited for overtures from apparent customers. If the other party made the first move, he reliably signaled that he was not an agent. The deal could then go forward. Deterring this kind of transaction required agents sometimes to imitate the parties who make the first move, in order to keep the criminals in doubt.

So too with tactics that are a lot more objectionable than mere solicitation. The logic here is that if a genuine criminal opportunity would have feature $X$, then stings must also sometimes have feature $X$, because otherwise the presence of $\mathrm{X}$ in a given setting will signal that the opportunity is genu-

81. It can affect the odds and expected penalty of a sting. It can also affect the "expected gain if genuine" term, by altering the likelihood and severity of ex post apprehension and punishment - a standard insight of the law enforcement literature.

82. These guidelines apparently have been abandoned in many jurisdictions. 
ine. X may of course be something so bad that, for moral reasons, it should be off-limits to agents. ${ }^{83}$ But making it off-limits means that genuine sellers can use it as a trademark.

\section{Frequency}

The inequality also implies a certain minimum frequency of offers made by undercover agents. Suppose that, for a given target group of individuals, the gain/penalty fraction on the right-hand side of the above inequality is 1/10. Then deterrence requires that, on average, at least 10 percent of the offers to these individuals come from undercover agents. The would-be crooks must know that about 10 percent of the opportunities they get are stings. As the right-hand fraction goes up, so must the left-hand side. The more attractive real opportunities become, the more lemons that must be put into circulation to make criminal acts undesirable. ${ }^{84}$

This does not mean stings should be indiscriminately aimed at everyone in the population. If anything, it means the opposite. Police resources are limited; raising the probability of a sting for one person entails a lost opportunity to raise the probability for someone else. It serves no deterrent purpose to throw resources away on targeting individuals who are unlikely to break the law in the first place. This merely dilutes the deterrent value of sting operations. The deterrent value is greatest if everyone understands that the police are concentrating their resources on those who most "need" to be deterred.

\section{TENSIONS BETWEEN INFORMATION AND DETERRENCE}

So far we have highlighted the distinction between the informational and behavioral purposes of sting operations. We turn now to an equally fundamental point: the purposes are not only different; they are in large measure incompatible. Pursuing deterrence sometimes frustrates the goal of sorting the crooked from the law-abiding.

83. Consider United States v. Skarie, 971 F.2d 317 (9th Cir. 1992), in which the agent threatened to kidnap the target's child if the target did not come up with some narcotics. Id. at 318-19.

84. Genuine sellers of the illegal good may sweeten their offers in response to the presence of phony sellers in the market. (Compare warranties in the auto market.) For example, they may lower their prices in order to offset the risk that the buyer may be caught in a trap. The government must then make offsetting adjustments so that, in equilibrium, the number of lemons is too great to make purchase worthwhile at the new prices offered by genuine sellers of illegal goods. 


\section{A.Publicity}

We briefly alluded to one respect in which this is true. When the objective is to identify crooks, to catch them in the act, the police want to keep the existence of undercover agents as hushed up as possible. If the crooks whom the police want to catch red-handed suspect that traps are being set for them, they will take evasive measures, ${ }^{85}$ making them harder to catch. This frustrates the hope that that they will walk into a trap in the false belief that it is a genuine criminal opportunity. The point here is simple: when gathering information is the object, the less crooks expect traps, the better.

Deterrent stings have the opposite property. If the objective is to deter criminals, the authorities want to create the impression that there are traps everywhere. Of course, as with informational stings, this requires making the traps indistinguishable from real criminal opportunities; stings are selfdefeating if they are recognizable to would-be offenders. ${ }^{86}$ But the hope is to make every genuine opportunity seem a possible trap. In contrast, with informational stings, the hope is to make every sting seem a genuine opportunity. Thus, while informational stings should create a false sense of security for crooks, deterrent stings should create a false sense of insecurity. A choice must be made between these strategies.

\section{B. Ensnaring the Innocent}

There is a more troubling conflict between the informational and deterrent uses of stings. The conflict can be easily stated: deterrent stings often require the use of baits, or traps, that run a strong risk of ensnaring the innocent, that is, people who would never otherwise have committed a crime. This is true in two basic respects.

\section{Predisposition}

Courts are fond of saying that stings should be used to ferret out people who are "predisposed" to commit a given crime before being approached by agents. But many crimes occur in which the defendant has no evident predisposition before being approached by agents. To take one example among

85. The evasion might be desirable, if it leads the individual to become a law abider. But it may take less desirable forms: the crooks may continue to commit crimes but take greater care to ensure they are not dealing with undercover agents.

86. There are many stories of stings that flop because agents were easily identified as such. An amusing and sometimes tragic example, often recounted by cops: police officers have often been required to drive specific makes of American cars when impersonating drug dealers. This has made them stand out like a sore thumb, because real drug dealers often prefer flashy foreign cars and can easily spot police vehicles. Stings have failed, and cops have been shot, as a result. 
many, in People v. Karraker, ${ }^{87}$ the defendant, a gun expert who often made silencers and other illegal paraphernalia for crooks, was convicted of converting a lawful rifle into an illegal fully automatic machine gun at the urging of some government agents. ${ }^{88}$ The court threw out the case, convinced that he was not predisposed to make a machine gun before the agents approached him because the idea was implanted in his mind by the agents. ${ }^{89}$ Perhaps so, but surely there is a strong deterrence argument that people in Karraker's line of work should fear that anyone who makes such a request may be an agent. On another day, a real crook might have approached Karraker with the same request. In short, a predisposition requirement blunts deterrence.

\section{Inducements}

There is a second type of conflict, which will occupy more of our attention. Put aside the issue of predisposition; focus now on the types of inducement employed to get the target to commit the crime. As we saw above, if deterrence is the aim, stings should use the same sorts of inducements that are found in the real world of crime, that is, in genuine criminal transactions. But, critically, the real criminal world may involve inducements that are not diagnostic, that is, inducements to which the normally law-abiding may easily succumb. To deter their acceptance, the same types of inducements must be used by the authorities. ${ }^{90}$ If the authorities forswear such inducements, then the recipient of such an inducement will know it is genuine and will be more tempted to accept. It follows that deterring crooks will entail catching innocents.

To generalize the point, suppose that in a given criminal market, inducements A and B are commonly used in real illegal transactions. Assume that inducement $\mathrm{A}$ is highly diagnostic, meaning that only the criminally disposed - those who are eager and likely to participate in the criminal marketwould accept it. In contrast, assume that inducement B is non-diagnostic, meaning that even the non-criminally disposed would be prone, for whatever reason, to accept it. (Perhaps $B$ is a large amount of cash or a threat.) If undercover agents are only permitted to use inducement $\mathrm{A}$ in sting operations, then they are in effect allowing B to become a "trademark" or "warranty" of

87. 633 N.E.2d 1250 (IIl. App. Ct. 1994).

88. Id. at 1251-52.

89. Id. at 1259.

90. Allen et al., supra note 3, argue that the inducements used by the government should be no greater than those used in the genuine criminal market. But that is only true if the government's purpose is to identify crooks. There may be some deterrent value in having potential crooks know that they will occasionally be receiving very attractive offers, and so should decline these as well as ordinary offers. Naturally, the government must be careful here; if the offer is too good to be true, the target may recognize it as a trap. 
genuineness. The recipient of an offer of B knows he is not the target of a sting and can proceed accordingly.

The only way to prevent this is to create a market of "lemons" in inducement B-that is, to let the world know that there are undercover agents out there offering B. The hope is to lead individuals to resist offers of B. Yet this creates a new difficulty: if agents go around offering B, they may, to the extent deterrence fails, garner acceptances from the non-criminally disposed. Indeed, they may wind up ensnaring people who never would have been offered $B$ in the real world, and so would never have committed any crime at all were it not for the sting operation.

Let me give a pertinent example. Suppose the government wants to deter people from assisting terrorist organizations. Suppose further that terrorists often use pressure tactics in order to obtain the assistance of others. ${ }^{91}$ We will assume that anyone who lends such assistance commits a crime. ${ }^{92}$ To achieve its deterrent aims, the government must have its undercover agents employ similar pressure tactics (and publicize the fact that they will be doing so). Yet when agents employ pressure, some targets will inevitably succumb to iteven though they are not inclined to assist terrorists, and perhaps never would have been approached by a real terrorist. So the trap, necessary for deterrence, inevitably catches some innocents who never would have committed the crime in question.

This problem would not occur if complete deterrence could be achieved. In our example, suppose that, by announcing that its agents would be mimicking all of the recruitment tactics used by real terrorists, the government managed to deter everyone from succumbing to the inducements, including pressure, offered by terrorist organizations. Then no one would be caught in a government trap since everyone would resist the blandishments of all recruiters, real or phony. But this will never happen in practice. If traps are set, some will be caught in them.

The problem of ensnaring the innocent would also go away if government agents could identify non-criminals in advance, avoid setting traps for them, and release those who were inadvertently caught. Suppose traps caught only those who, in the absence of the traps, would be successfully recruited by terrorists. If the existence of the traps were publicized, some of these individuals would be deterred from becoming recruits; others would walk into the government's traps. In either case, there would be no danger of ensnaring the innocents who never would have lent assistance to terrorists. But this, too, is unrealistic. Uncertainty pervades law enforcement. No one can suppose that those caught in stings will be limited to would-be offenders.

91. For instance, a terrorist might make threats in order to get a reluctant person to hide or transport weapons, money, confederates, and so forth.

92. We put aside cases involving pressure so severe (such as a gun held to the head) that the individual has a defense of duress or necessity in a subsequent prosecution. 
A further problem is convicting non-offenders who are caught in traps. If the authorities (prosecutors, judges, juries) could identify these individuals ex post, there would be no danger of convicting them. ${ }^{93}$ But this too is a matter of probabilistic judgment and no system is guaranteed to acquit the nonoffender while still achieving the enforcement purposes of stings. The challenge then is devising an optimal probability for conviction.

\section{AN ANALYSis of Optimal Sting Policy}

\section{A. The Model}

Let us now consider the properties of a desirable sting operation, judged in terms of the crime it reduces relative to the innocents it ensnares. Assume that the authorities launch a sting operation against a group of individualsfor example, offering bribes or other inducements to airline baggage handlers to allow agents to smuggle forbidden items on flights. ${ }^{94}$ The targets of the sting may be criminals (likely to permit smuggling even in the absence of the sting) or law abiders (unlikely to permit smuggling in the absence of the sting). Even if an individual is a criminal, the knowledge of the possibility of a sting may discourage him from accepting the blandishments of any smugglers, real or phony.

Figure 2 depicts the sequence of events in the sting. An agent sets a trap, offering big money to a baggage handler. The target may be a criminal or a law abider. If he is a criminal who has been scared off by the prospect of sting operations, he will reject the offer. This might be too strong an assumption; an individual might be deterred from taking offers that seem suspicious, while remaing open to offers that are clearly geniune. We make the asumption for purposes of expository clarity; little of the qualitative analysis would change if we dropped it.

If he is a criminal who has not been scared off by the prospect of a sting, he may or may not accept the offer. Likewise, if he is a law abider, he may or may not accept the offer. The theory here is that as a law abider, he pays less attention to police enforcement policy, including the prospect of sting operations, than do crooks.

The model is quite simple in other ways. We do not explicitly model the payoffs to individuals from accepting or resisting a smuggling offer, whether real or phony. Nor do we specify what knowledge they have about the likelihood that an offer is real or phony. We therefore do not attempt to

93. There would remain the problem for the defendant of mounting a costly defense and perhaps spending time in pretrial detention.

94. Such stings to check for baggage handlers being bribed into permitting the smuggling of unlawful weapons and explosives were undertaken at a number of airports-interestingly, even before the September 11 th disaster. See, e.g., American Air Staff Arrested in Drug Case, WALL ST. J., Aug. 26, 1999, at A4. 
predict the equilibrium behavior of criminals and law abiders when faced with the sting. We simply take as exogenous their decision whether to accept an agent's offer.

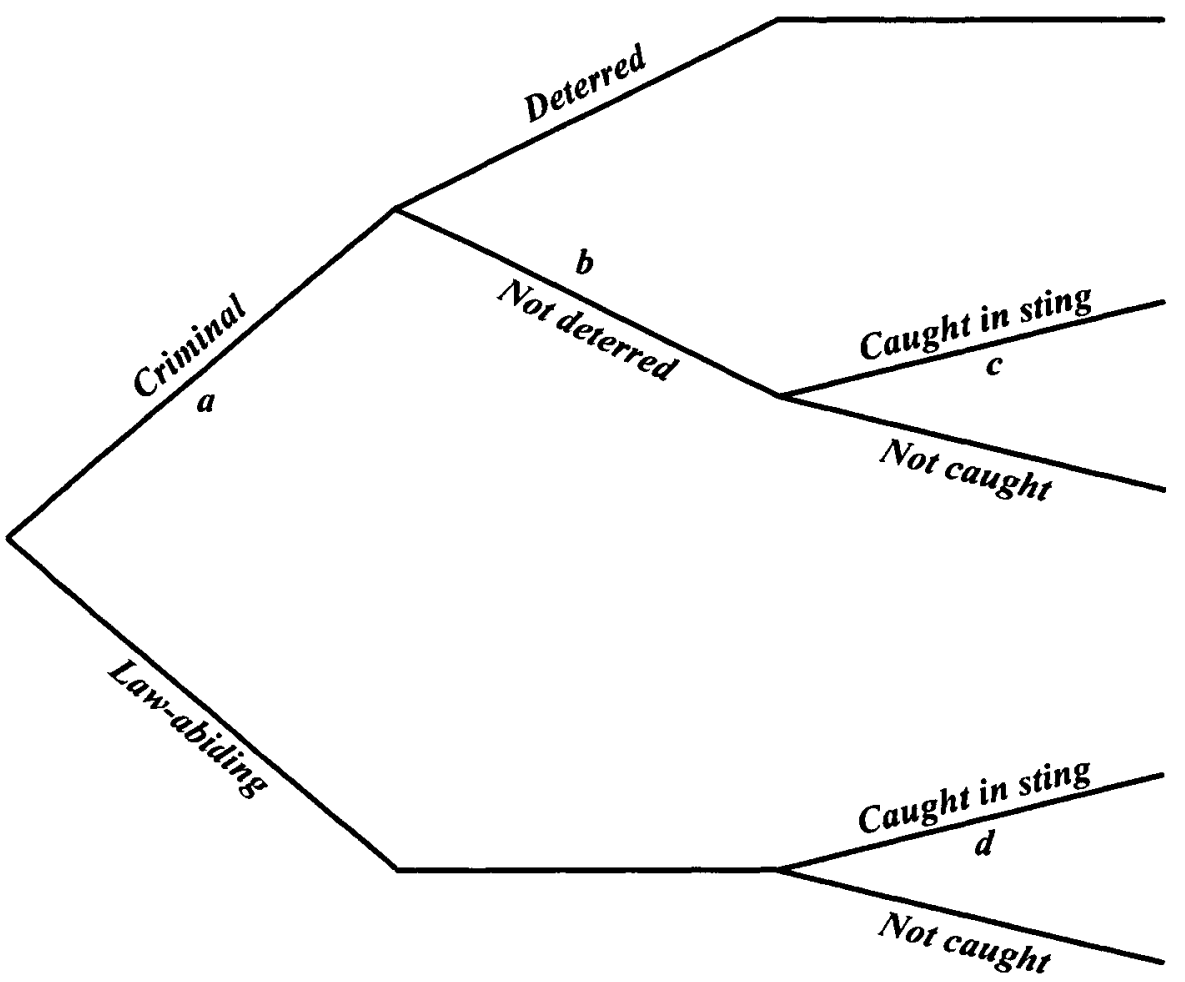

Figure 2 - Possible outcomes of sting operation. For simplicity, it is assumed that deterred criminals are not caught in stings. The $a, b, c$, and $d$ terms are employed in the appendix and can be ignored here.

For policy purposes, the key question is whether the value of catching or deterring offenders is worth the risks the operation poses to the innocent. ${ }^{95}$ We will look at this problem from two points of view. First, we will look at it from the perspective of the law enforcement officials who decide whether to undertake the sting operation. Next, we will look at the problem from the perspective of the authorities-prosecutor, judge, jury - who decide whether to indict and convict an individual who has been caught in the trap.

95. We ignore other costs of the operation, such as its opportunity costs to law enforcement or other indirect effects. 


\section{B. The Decision to Undertake the Sting Operation}

The authorities are considering whether to launch a sting operation against baggage handlers at major airports around the country. ${ }^{96}$ The target population may be a subpopulation of individuals who, for some reason, have come under suspicion of being susceptible to bribes; or the target population may be a random selection of baggage handlers. For present purposes, it makes no difference. All that matters is that the authorities are unsure which members of the target population, if any, are offenders.

The authorities are also unsure which of the people caught in the sting, if any, will be convicted of the crime. That choice is left up to subsequent decision makers, who may conclude that certain sting victims are innocent (more precisely, that the odds that they are offenders are insufficiently high to secure convictions). Not every sting victim will be convicted. As we emphasized before, it is generally pointless to punish a sting victim whose likelihood of being an offender is insufficiently high. So the authorities launching the sting must consider the likelihood that those caught in the trap will be convicted.

The objective of the authorities is to launch the sting if its expected costs are lower than not using it. The costs of not using the sting may be designated [\# of offenses that occur without the sting $\times$ costs of an offense]. Similarly, the costs of the sting are [\# of offenses the sting fails to prevent $\times$ costs of an offense] $+[\#$ of nonoffenders convicted in sting $\times$ costs of convicting a nonoffender]. ${ }^{97}$ Some simple algebraic manipulation ${ }^{98}$ shows that using the sting has lower expected costs than not using it if the following holds:

\section{$\frac{\text { \# of offenses prevented by sting }}{\# \text { of nonoffenders convicted in sting }}>\frac{\text { harm of convicting a nonoffender }}{\text { harm of an offense }}$.}

Note that all of the items in this expression should be understood in expected terms, at the time the decision whether to launch the sting is made.

First, consider the left side of the expression. The phrase "\# of offenses prevented by sting" refers to crimes that are prevented either by deterring offenders or by convicting and punishing offenders who fall into the trap. Observe that there is a complex relation between the numerator and denominator of the fraction. As we discussed in Part IV above, there is some possibility that the more effective a sting is at deterring offenders, the greater the risk of catching innocents in a trap. Thus, it may be that as the numerator rises, so will the denominator.

96. As is done periodically. See supra note 94.

97. For clarity of expression, we put aside the costs that may be incurred by an innocent sting victim who is acquitted (costs such as harm to reputation). These can easily be incorporated into the analysis.

98. See the Appendix for a formal derivation of the expression in the text. 
Whether and to what extent this happens depends on how well the authorities can, either ex ante (before the trap is set) or ex post (after a person is caught in a trap) sort offenders from nonoffenders. Examples of ex post sorting would be a prosecutor's decision to drop charges against, or a judge or jury's decision to acquit, a person who is considered an innocent who never would have committed the crime if not lured into doing so. (What level of belief is needed for this ex post decision is taken up below.) The better the authorities are at either ex ante or ex post sorting of offenders and nonoffenders, the greater the expected value of the left-hand side of the expression.

Next, consider the right-hand side of the expression. This fraction essentially captures the importance of avoiding false convictions versus the importance of preventing offenses. This may vary greatly. The numerator depends in part on the severity of the punishment suffered by including noncriminal penalties such as dismissal from a job by an employer. The denominator obviously depends on the nature of the offense: violent crime or espionage cause greater harm than traffic offenses, for example.

Notice that here too, though, the right-hand side is deceptively simple. The numerator and denominator are not necessarily independent of each other. The worse the offense, the greater the sanction is likely to be. And the greater the sanctions are, formal and informal, the greater the harm of convicting an innocent person. Moreover, it may be that the two denominators in the expression are not independent: the greater the harm of an offense, the more (or perhaps less) likely a nonoffender caught in a trap is to be mistakenly convicted. ${ }^{99}$

A final point about the expression is that the harmfulness of an offense does not necessarily strengthen the case for launching a sting operation. True, all else being equal, the greater the harm of an offense, the more likely the expression will be satisfied. For example, all else being equal, a sting aimed at terrorism is more valuable than a sting aimed at trafficking in stolen goods because the right-hand denominator is greater in the case of terrorism. But for reasons just noted, increasing the right-hand denominator may increase the right-hand numerator and left-hand numerator. So the impact of the harmfulness of the offense is at least ambiguous.

\section{The Decision to Convict}

Now let us turn to the question whether to convict someone who has been caught in a sting. (Again, conviction should be understood broadly to include civil sanctions and the like, depending on the context.) Assume that a particular individual has been caught in a trap. There is a certain probability that he is an offender. That probability, as we saw in Part II above, is a

99. This is a difficult question. Juries may be more concerned about avoiding errors when serious crimes are involved. But the opposite is also possible. 
function of the background information on the individual and the diagnostic value of the trap. How high should that probability be to warrant convicting him?

We noted above the possibility of simply convicting everyone who falls into the government's trap. For a variety of reasons, though, this approach seems distinctly inferior to one that would evaluate the defendant's criminal propensities. We saw in Part III that effective deterrence may require the use of baits that lure non-criminals into their traps. The costly process of prosecuting such individuals would needlessly dilute the deterrence exerted on the true criminals. Hence there is an argument for undertaking some effort to sort the true criminals from the unfortunate innocents who have been drawn into the government's web. That is, there is an argument for setting a threshold probability that a sting victim is a true criminal; if he falls below that threshold, he should be acquitted (on grounds we call "entrapment"). So again the question: what should that threshold probability be?

The essential tradeoff here is between preventing crime and preventing convictions of nonoffenders. If the threshold probability for conviction is set very low, then many nonoffenders will be convicted. But if the threshold probability for conviction is set very high, then offenders caught in traps will be freed, and (more importantly) other offenders will not be deterred from committing crimes. Thus some balance must be struck between these dangers in choosing the appropriate threshold probability for conviction. ${ }^{100}$

Analytically, the problem here resembles the problem just analyzed, of deciding whether to launch a sting at all. There is, on one hand, the relative harm of false convictions versus the harm of the offense. There is, on the other hand, the relative effectiveness at preventing the offense versus the likelihood of false convictions. The precise expression of the optimal probability involves a cumbersome degree of notation. It is easier to express the solution in term of odds, as we did in Part II. Drawing on the analysis of the previous problem just analyzed, we find that the optimal threshold for conviction can be expressed as follows:

\section{Odds defendant is an offender >} $\frac{\text { harm of convicting a nonoffender }}{\text { harm of an offense }}-\frac{\text { \# of offenses deterred by sting }}{\text { \# of nonoffenders caught in sting }}$.

As the expression indicates, the crucial elements in determining whether to convict are the harm of convicting a nonoffender relative to the harm of an offense, and the number of offenses prevented versus the number of

100. Related work, cutside the context of sting operations, has been done on the problem of setting the right threshold probability for conviction. See Michael L. Davis, The Value of Truth and Optimal Standards of Proof in Legal Disputes, 10 J.L. ECON. \& ORG. 343 (1994); Kaplow, supra note 65; Thomas J. Miceli, Optimal Prosecution of Defendants Whose Guilt Is Uncertain, 6 J.L. ECON. \& ORG. 189 (1990). 
nonoffenders caught. Notice that once again, all else being equal, the more harmful the offense, the lower the threshold probability needed to convict.

A point worth emphasizing is that this expression can be used to interpret either the "subjective" approach to entrapment (in which the focus is on the individual defendant) or the "objective" approach (in which the focus is on the average defendant who could be caught in the sting). If the subjective approach is preferred, "defendant" in the left half of the expression should be construed as the individual defendant. If the objective approach is preferred, the term should be construed as the average defendant that would, or might, be ensnared in the government's trap.

Because we are generally more inclined to think of uncertain events in terms of "probability" rather than "odds," general sense of the probability required to convict. The horizontal axis is simply the third term in the above expression, that is, the expected number of offenses deterred by convicting the sting victim versus the expected number of innocents who will be caught in the sting. For lack of a better term, I call this the "deterrence value" of the sting. I have arbitrarily limited the domain of this axis to 10 offenses deterred per nonoffender caught in a trap.

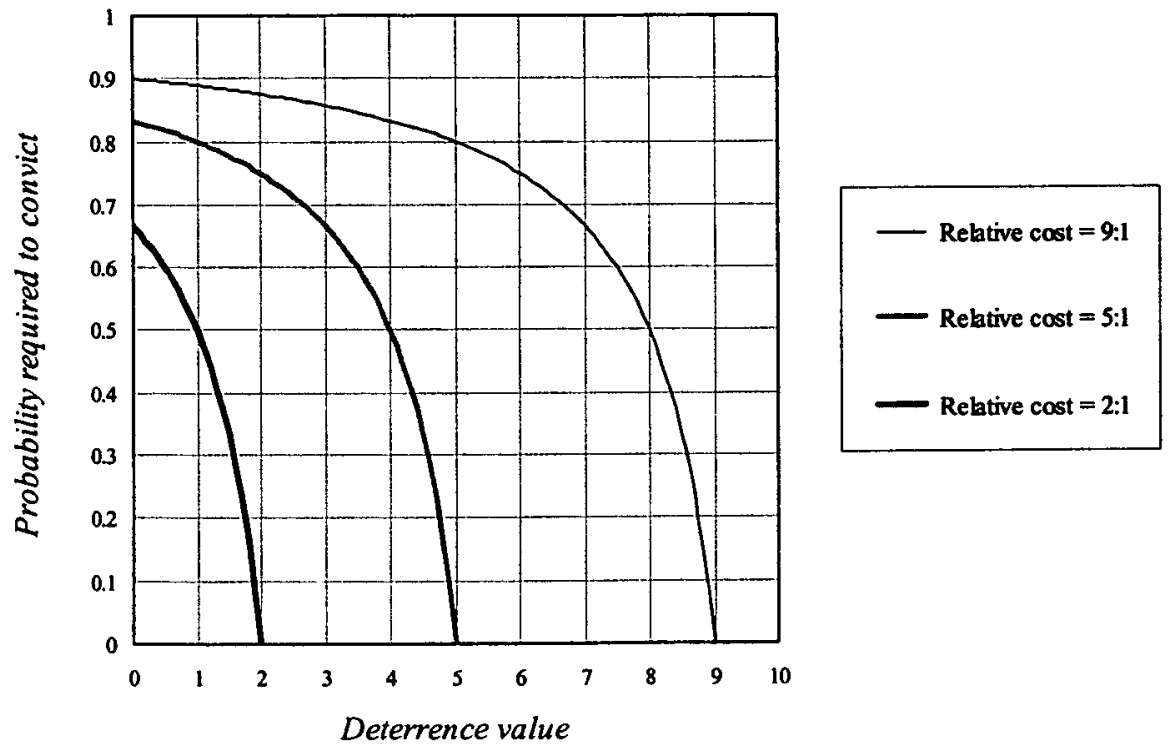

Figure 3 - Probability required to convict, given deterrence effect and relative cost of erroneous conviction.

101. If the odds of an event are $x$ (that is $x$ to 1 ), then the corresponding probability is $x /(x+1)$. Thus, if the odds are, say, 4 , this means that there is a 4 to 1 chance that the individual is an offender; this is equivalent to saying that there is a $4 / 5$ chance, or .8 probability, that the individual is an offender. 
Then there is the second term in the expression-the cost of convicting a nonoffender caught in a trap versus the harm of an offense. I denote this the "relative cost of error." Three randomly chosen values of this term are contained in the small box at the right of the figure.

The figure indicates the probability required to convict, given the combination of deterrence value and the three arbitrarily chosen relative costs of error in the box at right. The dependent variable (the $y$ axis) is the probability required to convict. So, to take an example at random, if the relative cost of error is 5 to 1 and the deterrence value is 4 , then the probability required to convict would be .5 . Thus, the decision maker would have to be at least 50 percent certain that the defendant is an offender-one who would have committed an offense independently of police inducement. ${ }^{102}$ If the probability is less than that, the defendant should be acquitted on "entrapment" grounds-he has committed the crime (with police help), but the costs of convicting him exceed the costs of the acquittal.

\section{SOME APPLICATIONS TO ENTRAPMENT DOCTRINE}

In our brief overview of entrapment doctrine in Part I, I identified several problems that courts have had to confront: (1) should there be an entrapment defense? (2) if so, should a "subjective" approach (looking at the individual defendant's proclivities) or "objective" approach (looking at the methods used by the police) be the touchstone of entrapment; (3) regardless of the approach, by what standard of proof should the entrapment defense be proved in a given case?

The foregoing analysis provides solid support for allowing an entrapment defense, because one can imagine sting operations that would ensnare individuals without being needed for either informational or deterrent goals. For example, offering an individual an extraordinary sum of money to commit a minor offense provides little information about whether he would commit such a crime in the real world, where such extraordinary rewards are not available. Nor is it needed for deterrence, which requires only that the government mimic the inducements held out in the real world to would-be criminals. It is not surprising, therefore, that a defense of entrapment is allowed in every American jurisdiction.

But on the second and third questions, the model provides less guidance. In part, the difficulty lies in whether the aim of stings is to provide informa-

102. Under the "subjective" test-that is where the court is worried about the proclivities of the individual defendant-the figure would be 50 percent for the defendant in question. Under the "objective" test, where the court is concerned with the average person who would be caught in the trap, the relevant figure would be 50 percent for the average defendant. 
tion (as most courts seem to think) or to deter. If the main goal is to identify crooks, then using a subjective approach-i.e., looking at all the information available about the defendant (his background and reputation as well as at the diagnostic value of the sting)-is probably more sensible than focusing exclusively on the diagnostic value of the sting. Perhaps this explains why most courts use some variant of the subjective approach, i.e., take account of features of the defendant other than the mere fact that he took the bait. However, if deterrence is the goal, then there would be less argument for looking at the properties of the individual defendant: the government would want to telegraph the message that anyone who takes a given opportunity runs the risk that it is a "lemon" that will land him in jail. Giving him the chance to show that he personally is not the criminal type would not materially advance deterrent goals. Thus, one can make a case for either the subjective or objective approach, which may explain why they coexist in this country.

Finally, on the matter of what standard of proof should be employed in entrapment cases, the model only tells us the relevant parameters, without specifying their value. Obviously, their value would vary across different classes of cases, which would imply different standards of proof for these classes. All else being equal, for example, the more harm a court perceives in convicting a nonoffender (i.e. one not predisposed to crime), the greater the standard of proof should be. Perhaps the variation we see on the standard of proof issue - some courts requiring proof beyond a reasonable doubt, others requiring something less-reflects differences of opinion on how bad it is to jail someone who might never have committed a crime but for the government's instigation.

The model does, however, yield two relatively firm principles to guide courts' thinking in the entrapment area. First, as a theoretical matter, there is no necessary relation between the informational or investigatory functions of sting operations on the one hand, and the deterrent functions of sting operations on the other. Punishing sting victims-that is, people who succumb to criminal inducements - may have considerable deterrent value even if the sting reveals little or nothing about their previous criminal proclivities. Indeed, for reasons examined in Part III, effective deterrence may require the use of criminal inducements that may tempt the non-criminally predisposed into committing offenses. For deterrence to work, there cannot be any "trademark" inducements that only real criminal recruiters are permitted to use.

Second, for practical purposes, a rule enforcer would want to take into account both effects-informational and behavioral-in deciding whether to impose sanctions on a sting victim. This is true in the public enforcement arena, both in criminal and civil law violations. It also holds for private enforcement, such as decisions by employers or other organizations. As noted before, however, sting victims get the protection of the entrapment defense only when they are criminally prosecuted for falling into a police trap. The optimal rule for setting a trap and convicting those who fall into it is set forth 
in the models in Part V, which include both the deterrent and informational aspects of police traps.

Which raises the question why so many courts see the informational function as the only legitimate one, in the sense that they will only convict a sting victim if the sting has revealed, or tends to reveal, those who were crooked before being approached by the government agent. There are a thousand judicial opinions to the effect that the proper business of police is to fight crime, not create it. But this is no answer to the question because the ex ante effect of offering criminal inducements has the effect of reducing the crime rate. Some court opinions have recognized the deterrent value of stings; but these are buried under the many opinions suggesting that the sole purpose of stings is to ferret out criminals.

Perhaps the courts' reasons are fully explained by the dangers we catalogued earlier: ${ }^{103}$ the risk that stings will be used to harass political dissidents, the waste of police resources on targeting harmless individuals who would never have otherwise committed a crime, the corruption invited by allowing police to get mixed up in criminal enterprises, the symbolic erasure of the state's moral authority, even the courts' fear that they are being "prostituted" into creating criminals instead of ridding society of them. Honoring these admittedly legitimate concerns, though, comes at the cost of the deterrent value that would be realized by giving the police greater leeway in the inducements employed and in the selection of targets.

Other questions are posed by the courts' contemporary stance toward entrapment. Consider the burden of proof that the prosecution must shoulder on the question of entrapment. The federal courts, and many state courts, require the prosecution to prove beyond a reasonable doubt that the defendant was predisposed to commit the crime the agent induced him to commit. ${ }^{104}$ In jurisdictions that employ the "objective" test, the prosecution must prove beyond a reasonable doubt that the trap would not have led an average lawabiding person to commit the crime.

In terms of the expression and accompanying figure 3 above, this is equivalent to saying that the relative cost of erroneous convictions is very high. But this poses a puzzle. No one doubts that the relative cost of convicting a person innocent of the crime charged is very high. ("Better ten guilty men go free than one innocent man be hanged." ${ }^{105}$ But here we are not speaking of innocence in the ordinary sense. There is, by assumption, no question that the defendant is guilty of the crime charged. The question is whether he (or an average person) would have committed it without the encouragement of an undercover agent. Whether an error on that question is of

103. See supra part II.

104. Again, no one doubts that the state must prove beyond a reasonable doubt that the defendant in fact committed the crime. The question is whether he was entrapped into doing so. 65.

105. Others would put the ratio much higher- -99 to 1, or more. See supra note 
comparable magnitude to an error on the question of factual guilt is hardly obvious.

Return to our earlier example of the airport baggage handler who is bribed by an agent into allowing forbidden items on a flight, and assume there is some question whether this handler would have committed such a crime had a trap not been set for him. This person is undoubtedly less culpable than a baggage handler who readily accepts bribes from real smugglers. Yet he has committed a crime, and is therefore probably more culpable than someone who never accepted any bribe, from either an agent or a genuine smuggler. So the person who commits only government-engineered crimes lies somewhere between the person who commits no crime and the person who commits genuine crimes.

This might be taken to imply that the relative cost of error on the question of entrapment is lower, all else being equal, than the relative cost of error on the question of factual guilt. If so, the government's burden of proof on the question of entrapment should be correspondingly lower. Of course, nothing in the model says where the burden should lie. The relative cost of error, as with the other terms in the expression and figure in Part IV.B, is exogenous to the model. It is worth noting, however, that whatever the government's burden, the entrapment defense rarely succeeds, perhaps because so many defendants have long criminal records.

Another puzzle is the treatment of individuals who are willing but not able to commit their crimes without the assistance of government agents. In United States $v$. Hollingsworth, ${ }^{106}$ the defendants, an orthodontist and a farmer, decided to try their hands at international money laundering-"a vocation for which neither had any training, contacts, aptitude, or experience." ${ }^{107}$ They formed a Virgin Islands corporation and put an ad in the paper, which was spotted by a U.S. Customs agent who set them up in a laundering operation and then arrested them. ${ }^{108}$ The court of appeals threw out their conviction, holding that "predisposition" is not enough to overcome an entrapment defense; the defendants must also be in a "position" to commit their crime without the government's help. ${ }^{109}$ "No real criminal would do business with such tyros," according to the court, ${ }^{110}$ making prosecution and conviction a pointless exercise.

Other courts have taken the opposite position, saying that the government need not prove that the defendants were actually able to carry out their criminal designs. ${ }^{11}$ The issue remains unresolved in the courts. Our model has implicitly assumed that a criminal is someone predisposed but also able to

106. 27 F.3d 1196 (7th Cir. 1994) (en banc).

107. Id. at 1200 .

108. Id.

109. Id.

110. Id. at 1203.

111. See United States v. Thickstun, 110 F.3d 1394, 1398 (9th Cir. 1997). 
commit the crime on his own; but the model is easily adjusted to redefine a criminal as someone who is not merely predisposed to commit a crime but is actually capable of pulling it off. With that adjustment, the analysis carries through entirely.

\section{CONCLUDING REMARKS}

Earlier I noted some of the potential advantages of sting operations over other possible enforcement methods, such as pure surveillance, in which the government watches but does not participate in the target's crime, and ex post enforcement, in which the government waits for a crime to be committed and then searches for and gathers evidence against the perpetrator. To be sure, the line between these different strategies is fuzzy at the margins. One can imagine enforcement efforts that would involve a combination of them. (Efforts to fight the mob or terrorist organizations might easily involve all three.) One possible direction for future research might be to identify the conditions under which one or another strategy is best suited to particular types of crime, civil offense, or organizational infraction.

\section{APPENDIX}

The purpose of this Appendix is to formally derive the results in Parts II and $\mathrm{V}$ of the text. Assume that a given individual is either a criminal or lawabiding; ${ }^{12}$ the state does not know which. If he is a criminal, the state wants to either deter him or (if that fails) convict him. It may use a sting operation against individuals, possibly with some advance warning for its deterrent value. The probability that the individual is a criminal is $a ;^{113}$ if he is a criminal, the probability that he will not be deterred by the sting is $b$; if he is not deterred, the probability that he will be caught in the sting (take the bait) is $c .{ }^{114}$ If he is not a criminal, the probability that he will be caught in the sting is $d$. (It is assumed

112. The model takes as exogenous why some people are criminals or lawabiding. A model of why people fall into one or the other category would presumably take into account an individual's perceived benefits of committing crime, along with his perceived chances of being caught and the sanction he would receive. Thus, for example, if we let $B$ represent the perceived benefits of crime, $P$ the perceived chances of getting caught, and $S$ the perceived sanction upon being caught, we might say that each individual has a distribution of $(B, P, S)$; for criminals, $B>P S$, for noncriminals, $B<P S$. The existence of stings would change a given individual's distribution of $(B, P, S)$, and so might alter the rationale for targeting and convicting him. I thank Steve Shavell for these observations, though I have decided they would make the model overly complicated.

113. The term $a$ can be interpreted as the number of criminals on the street if no sting is used, net of the number of criminals caught or deterred by other methods.

114. For simplicity, we assume that if he is deterred, he does not succumb to the sting. 
that some noncriminals may fall into the government's trap, even though they would not commit crimes of their own.) These possibilities, and the corresponding notation, are depicted in the decision tree (figure 2) in Part V of the text.

Let $p$ represent the conditional probability that the individual is a criminal, given that he has taken the bait in the sting. By Bayes' rule, we have

$$
p=\frac{a b c}{a b c+(1-a) d} \text {. }
$$

Figure 1 in the text is derived as follows. Let $r$ represent the fraction $\frac{b c}{b c+d}$; this corresponds to what we called the sting's "reliability" in the text." Substituting $r$ into (1) gives

$$
p=\frac{a r}{a r+(1-a)(1-r)} .
$$

Figure 1 plots the pairs $(r, a)$ satisfying (3), given three arbitrarily chosen values of $p$.

Now turn to the analysis in Part V of the text. To determine the value ex ante of the sting operation, assume that society sustains harm $J$ if a criminal is neither deterred nor convicted, and sustains harm $K$ if a non-criminal is caught in a sting and convicted. Assume further that anyone who takes the bait in a sting is convicted with probability $q$. The expected cost of the sting operation is then $a b(1-c) J+a b c(1-q) J+[(1-a) d] q K$. The expected cost if the sting is not used is $a J$. Using the sting is preferable if

$$
a[(1-b)+b c q] J>(1-a) d q K,
$$

which may be rewritten as

$$
\frac{a[(1-b)+b c q)]}{(1-a) d q}>\frac{K}{J} .
$$

The numerator is the probability that an offender will be either deterred or convicted. The denominator on the left equals the probability that a law abider will be convicted.

We now take up the question of convicting someone who has been caught in a sting. Assume that there are other individuals in the population similar to the person caught in the trap; the degree to which they are deterred may depend on whether people like the defendant are convicted. We will use the same notation as above. ${ }^{116}$ The expected cost of convicting an innocent individual in the position of the defendant (that is with a comparable amount

115. The term $b c$ represents the conditional probability that a criminal will take the bait; the term $d$ represents the analogous probability for a non-criminal.

116. Notice that the decision maker may place a different value on the variables $a$ and $b$ than did the authorities who undertook the sting (because new information may have emerged). 
of evidence) is (1-a)dK. The expected cost of acquittal of a guilty defendant is $[a b c+a(1-b)] J$. Conviction is therefore preferable if

$$
[a b c+a(1-b)] J>(1-a) d K,
$$

that is, if

$$
\frac{a b c+a(1-b)}{(1-a) d}>\frac{K}{J} .
$$

Now, let $\Omega$ represent the odds that a person in the relevant subset is an offender. Applying the definition of odds $\left(\Omega=\frac{p}{1-p}\right)$ and incorporating expression (1), we have

$$
\Omega=\frac{a b c}{(1-a) d} .
$$

Then (6) can be rewritten as

$$
\Omega>\frac{K}{J}-\frac{a(1-b)}{(1-a) d} .
$$

In the second term of the right-hand side, the numerator is the probability that an offender will be deterred; the denominator is the probability that a law abider will be caught in a sting.

Figure 3 in the text is derived as follows. Let $x$ and $y$ denote, respectively, the terms $\frac{K}{J}$ and $\frac{a(1-b)}{(1-a) d}$. Substituting these terms into (9) and applying the definition of odds $\left(p=\frac{\Omega}{\Omega+1}\right)$ gives

$$
p>\frac{y-x}{y-x+1}
$$

Figure 3 plots the minimum pairs $(x, y)$ satisfying (9), given three arbitrarily chosen values of $x$. 
Missouri Law Review, Vol. 70, Iss. 2 [2005], Art. 2 